\title{
GRONINGEN RADIOCARBON DATES VII
}

\author{
J. C. VOGEL and H. T. WATERBOLK
}

University of Groningen, Netherlands*

\section{INTRODUCTION}

In late 1962 the old radiocarbon laboratory in Groningen was demolished and new dating equipment was erected in an underground cellar specially built for the purpose.

The combustion and purification line as developed by de Vries (1953) has undergone several changes in the course of time by which the preparation of samples has become somewhat simpler. The main improvements are the elimination of the $\mathrm{CaO}$-furnace which proved not essential, and the installation of a Cu-furnace through which the sample gas circulates automatically by thermal convection. It used to be necessary to pass the $\mathrm{CO}_{2}$ through a Cu-furnace six or more times before it was pure enough for measurement. The new "circulation" furnace has proven to be equally effective if the sample is left in it overnight.

The first section of the purification line consists of the following elements: CuO-furnace at $800^{\circ} \mathrm{C}$, silver-furnace, acid potassium permanganate, potassium, permanganate, dry-ice vapor trap, silver-furnace spiral vapor trap (dry-ice), and two liquid air traps where the $\mathrm{CO}_{2}$ from the combustion is condensed. After the excess oxygen and nitrogen is completely removed by pumping, the $\mathrm{CO}_{2}$ is passed through a furnace with copper and silver to the circulation furnace where it is left to circulate over heated copper overnight.

The apparatus for removal of radon (de Vries, 1957) has also been simplified. Instead of a rotating stirrer, a thick-walled copper tube in the center of the condensation vessel produces enough thermal convection to keep the gas phase well mixed while the $\mathrm{CO}_{2}$ is being condensed. Experiments have shown that radon is removed equally well with the new apparatus.

Completely new counting equipment has been installed in the new laboratory. The two counters in use for routine dating are made of quartz glass $\rightarrow$ with a conducting layer of tin oxide on the inner surface. As little other material as possible was used in the construction to minimize the possibility of incorporating unwanted radioactivity. Details of construction are shown in Fig. 1.

The counters are surrounded by $4 \mathrm{~cm}$ of old lead insicle the ring of anti-coincidence counters which are surrounded by $10 \mathrm{~cm}$ of specially selected lead.** On top of the shielding $20 \mathrm{~cm}$ of boron-paraffine and $20 \mathrm{~cm}$ of lead and iron has been placed. This addition reduced the background of the counters slightly. Finally the roof of the cellar is covered

* Physics Laboratory, Westersingel 34, and Biological-Archaeological Institute, Poststraat 6, Groningen.

† Heraeus Quarzsmelze G.m.b.H., Hanau, Germany. Quality “Heralux.”

** Boliden Aktiebolag, Stockholm, Sweden. 

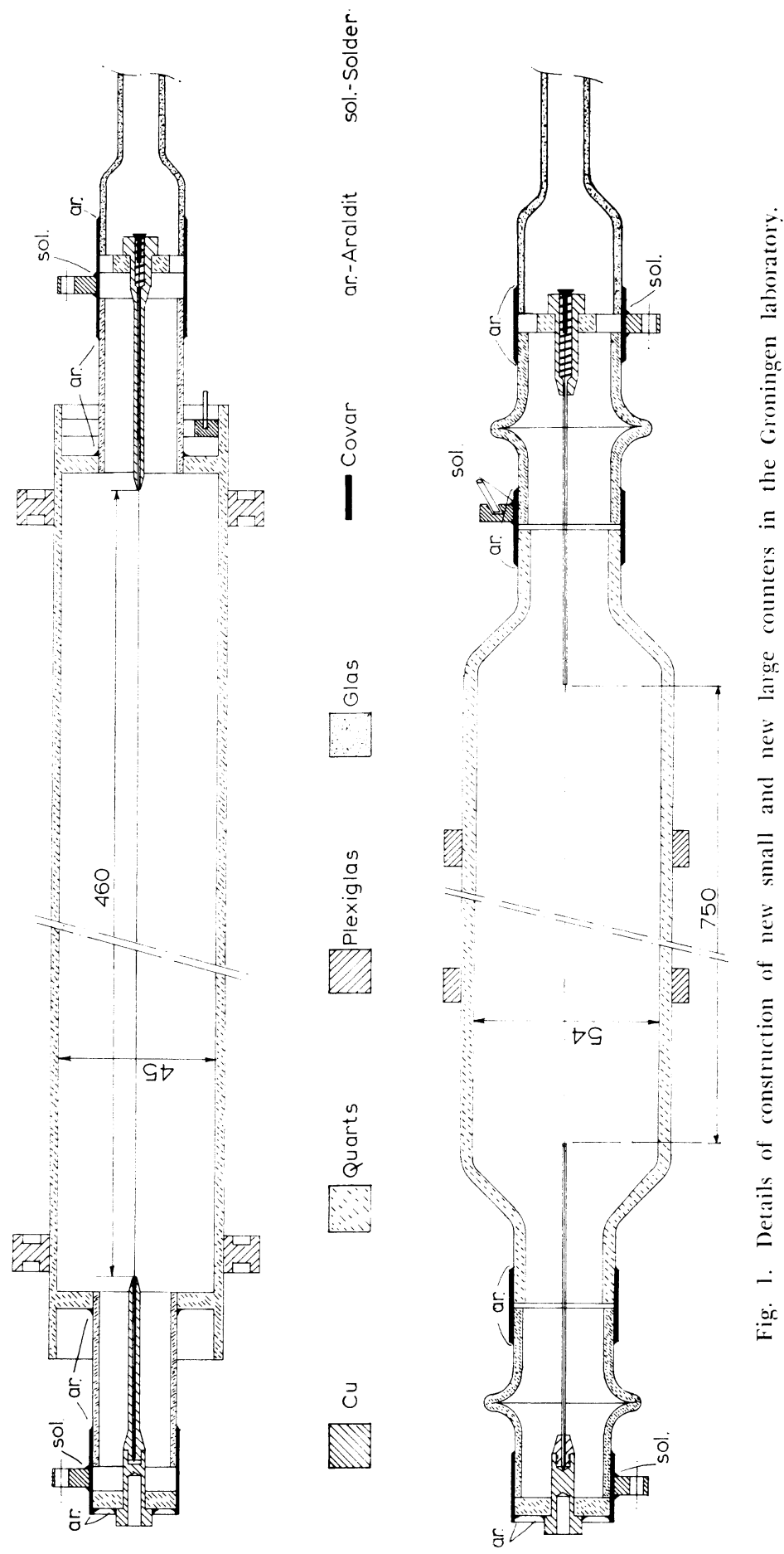
by $1 \mathrm{~m}$ of soil and concrete. The background of the counters has steadily decreased since installation in 1962-63 indicating that they were slightly contaminated by radioactive material with a half-life in the order of years. The total decrease to date is more than a factor two.

Details of the counter characteristics are as follows:

\begin{tabular}{ccccccc}
\hline Counter & $\begin{array}{c}\text { Eff. vol. } \\
\text { ml }\end{array}$ & $\begin{array}{c}\text { Pressure } \\
\text { torr }\end{array}$ & $\begin{array}{c}\text { Background } \\
\text { B, cpm }\end{array}$ & $\begin{array}{c}\text { Modern } \\
\text { Carbon } \\
\text { A, cpm }\end{array}$ & $\begin{array}{c}\text { Fig. of } \\
\text { merit } \\
\text { A/ V B }\end{array}$ & $\begin{array}{c}\text { Range } \dagger \\
\text { years }\end{array}$ \\
\hline RZ & 1700 & 2063 & 1.84 & 30.71 & 22.6 & 51,500 \\
LZ & 750 & 2139 & 0.85 & 13.28 & 14.4 & 48,000
\end{tabular}

$\dagger$ For a two-day count.

Apart from the steady decay, the fluctuations in background are not greater than are to be expected from counting statistics, indicating that there are no additional sources of variation. A correction of $0.0055 \mathrm{cpm}$ per torr barometric pressure for counter $\mathrm{RZ}$ is applied $(0.002 \mathrm{cpm}$ or LZ).

All analyses with GrN-numbers above 4000 have been performed in the new laboratory. Results are expressed in conventional radiocarbon years. In our laboratory W. G. Mook took care of the $\mathrm{C}^{13}$ analyses of most of the young samples. Where $\mathrm{C}^{13}$ measurements are available corrections for isotopic fractionation are applied to the dates and the $\mathrm{C}^{13}$ contents are given relative to the P.D.B. standard. The accuracy for routine measurements is less than $0.2 \% 0^{*}$

All samples are pretreated with acid and alkali unless otherwise stated. A number of dates obtained on unburned bone are included; details of the chemical pretreatment will be published elsewhere.

Only dates which have a bearing on archaeology have been included in this list. Sections I and VI have been prepared mainly by the first author and the rest by the second.

\section{SAMPLE DESCRIPTIONS}

I. PALEOLITHIC AND MESOLITHIC OF EUROPE, N. AFRICA AND THE NEAR EAST

\section{A. France}

\section{Gondenans-les-Moulins series, France}

Excavation in Grotte aux Ours at Gondenans-les-Moulins $\left(47^{\circ} 28^{\prime}\right.$ $05^{\prime \prime} \mathrm{N}$ Lat, 6 23' 09" E Long), dept. Doubs has revealed 3 layers containing badly defined Mousterian (Alpine Paleolithic ?) and many bones, mainly Ursus spelaeus sealed between 2 layers of stalagmite. Coll. 1963 and subm. 1965 by J. P. Jéquier, Areuse, Switzerland.

* Thanks are due to Mr. Mook for consenting to the publication of $\mathrm{C}^{13}$-values. 


\section{GrN-4629. Gondenans-les-Moulins 63-c2}

$48,300 \pm 2300$

Collagen from bone in Layer 2 just below upper stalagmite layer at 0.5 to $0.7 \mathrm{~m}$ depth, $25 \mathrm{~m}$ from entrance.

\section{GrN-4557. Gondenans-les-Moulins 63-c4}

Charcoal from base of Layer 4, just above lower stalagmite layer at 1.0 to $1.2 \mathrm{~m}$ depth, $25 \mathrm{~m}$ from entrance.

General Comment: two dates within statistical possibility the same. Average is $46,000 \pm 1000$ which is considered minimum for culture. Compare GrN-1477, Drachenloch: $>53,000$ (Groningen VI) and GrN4628, Salzofenhöhle: $>45,000$ (below).

\section{Grotte du Renne series, France}

In 1961 further samples from Grotte du Renne $\left(47^{\circ} 37^{\prime} \mathrm{N}\right.$ Lat, $3 \circ 45^{\prime}$ E Long), Arcy-sur-Cure, Yonne were subm. by A. Leroi-Gourhan, Musée de l'Homme, Paris (compare also Groningen IV, V and LeroiGourhan, 1961).

\section{GrN-4251. Grotte du Renne $\mathrm{X} b$, residue}

\section{GrN-4216. Grotte du Renne $\mathrm{Xh}$, extract}

Charred bone from Layer $\mathrm{Xb}$ thought to represent lower Châtelperronian culture. Depth $3.50 \mathrm{~m}$. Comment: treated as charred bone. The fact that both fractions give approximately same age makes result quite reliable. Date, however, is much too young when compared with GrN-1742, Grotte du Renne VIII: 33,860 \pm 250 B.P. (Groningen IV), for same culture. According to result sample would date from Upper Perigordian.

\section{GrN-4217. Grotte du Renne XII, residue}

$34,600 \pm 850$ 32,650 в.c.

GrN-4256. Grotte du Renne XII, extract

$33,700 \pm 810$ 32,750 в.c.

Charred bone from Layer XII containing Final Mousterian artifacts. Depth ca. $4 \mathrm{~m}$. Comment: treated as charred bone. As highest figure is considered most reliable, minimum age of 34,600 в.P. for Final Mousterian must be accepted. Compare GrN-2526, La Quina 2: 35,250 \pm 530 B.P. (Groningen IV), for Final Mousterian at La Quina.

\section{Les Cottés series, France}

At Abri des Cottés near Saint-Pierre-de-Maille $\left(\begin{array}{llll}46^{\circ} & 40^{\prime} & \mathrm{N} \\ \text { Lat, }\end{array}\right.$ $0^{\circ} 50^{\prime} \mathrm{E}$ Long), Vienne three culture layers with successively Mousterian, Lower Perigordian and Aurignacian are separated by sterile layers (Pradel, 1959; 1961). Cultural assignment of samples is therefore very re- 
liable. Unburned bone from each layer coll. and subm. 1959 and 1964 by L. Pradel, Châtellerault, Vienne.

GrN-4258. Les Cottés E-1, teeth

GrN-4296. Les Cottés E-2, bone

GrN-4509. Les Cottés E-3, bone $\mathbf{3 0 , 8 0 0} \pm \mathbf{5 0 0}$

28,850 B.c.

$31,000 \pm 320$ 29,050 в.c.

$31,200 \pm 410$ 29,250 B.c.

Collagen from animal teeth and bone from Layer $\mathrm{E}$ with Aurignacian I assemblage (with split bone points) at 1.6 to $2.0 \mathrm{~m}$ depth. Comment: despite slightly different pretreatment of samples all three dates are, within statistical uncertainty, the same and are considered reliable.

GrN-4333. Les Cottés G-1, teeth $\mathbf{3 3 , 3 0 0} \pm 500$ 31,350 B.c.

GrN-4510. Les Cottés G-2, bone $31,900 \pm 430$ 29,950 B.C.

Collagen from animal teeth and bone from Layer $G$ with Perigordian II assemblage (Châtelperron points and burins) at ca. 2.10 to $2.35 \mathrm{~m}$ depth. Comment: compare GrN-1742, Grotte du Renne VIII: $33,860 \pm 250$ B.P. (Groningen IV) for similar Châtelperronian industry.

\section{GrN-4334. Les Cottés I-1, bone}

GrN-4421. Les Cottés I-2, bone
$32,300 \pm 400$ 30,350 B.C.

$37,600 \pm 700$ 35,650 в.c.

Collagen from animal bone from Layer I with Mousterian industry (Abri Audi points) at ca. 2.70 to $3.00 \mathrm{~m}$ depth. Comment: GrN-4334 obviously still contains recent contamination. GrN-4421 was more thoroughly pretreated and gave much higher age. However, it is difficult to judge reliability of date because no comparison with similar dated Mousterian industries is possible.

\section{La Quina series, France}

Two further samples of Final Mousterian industry at La Quina $\left(45^{\circ} 30^{\prime} 35^{\prime \prime} \mathrm{N}\right.$ Lat, $0^{\circ} 17^{\prime} 59^{\prime \prime} \mathrm{E}$ Long), near Villebois-Lavalette, Charente, have been measured to check GrN-2526, La Quina 2: 35,250 \pm 530 (Groningen IV and Henri-Martin, 1964). Subm. 1965 by Mlle G. Henri-Martin, C. N. R. S., Paris.

GrN-4494. La Quina 3, extract

$$
\begin{aligned}
& 34,100 \pm 700 \\
& 32,150 \text { в.c. }
\end{aligned}
$$

GrN-4449. La Quina 3, residue

$$
31,100 \pm 400
$$$$
\text { 29,150 в.C. }
$$

Charred bone from Sec. C associated with Final Mousterian. Comment: sample treated as charred bone and both fractions measured. As 
frequently happens, insoluble fraction is younger than "bone fraction." Oldest date $(34,100 \pm 700)$ is to be accepted as most reliable. Within limits of statistical possibility figure is same as GrN-2526.

\section{GrN-4450. La Quina 4, residue}

$11,690 \pm 70$

Charred bone from $0.8 \mathrm{~m}$ depth at Sec. B, Layer 10 with Final Mousterian industry. Same section as La Quina 2 (GrN-2526). Comment: very young age suggests sample belongs to later habitation.

\section{GrN-4308. Regourdou, France \\ $45,500 \pm 1800$}

Charred wood from Layer 4 in Regourdou cave, SE of Montignac on Vézère R. (45 $3^{\circ} \mathrm{N}$ Lat, $1^{\circ} 10^{\prime} \mathrm{E}$ Long) close to Lascaux Cave, Dordogne. Five successive culture layers contain Mousterian assemblages of which Layer 4 is middle one. Apart from typical Mousterian artifacts, Layer 4 contained Neanderthal burial and stone heaps enclosing remains of bear. Stratigraphically Layer 4 is placed in "Würm I" (Bonifay, 1964). Coll. and subm. 1964 by E. Bonifay, Institut de Paléontologie Humaine, Paris. Comment: material consisted of good charred wood fully pretreated so that result should be reliable. However, dates in this age-range are never more than minimum.

\section{Combe-Grenal series, France}

Combe-Grenal cave near the town of Domme $\left(44^{\circ} 48^{\prime} \mathrm{N}\right.$ Lat, $1^{\circ} 12^{\prime}$ E Long), Dordogne, has more than 30 Mousterian layers probably representing continuous occupation since Acheulian times. Profile in Bordes (1955). Samples from Layer E2 with Mousterian artifacts of "denticulée" type. Coll. by F. Bordes during excavation. E2 is overlain by two more Mousterian layers. Subm. by F. Bordes, Univ. of Bordeaux.

\section{GrN-4304. Combe-Grenal 1, extract}

$39,000 \pm 1500$

Charred bone and ash from Layer E2. Coll. 1959. Comment: treated as charred bone (cf. Groningen IV) and alkali soluble fraction measured.

\section{GrN-4311. Combe-Grenal 2, residue}

$$
\begin{aligned}
& \mathbf{3 0 , 3 0 0} \pm \mathbf{3 5 0} \\
& \mathbf{2 8 , 3 5 0} \text { в.C. }
\end{aligned}
$$

\section{GrN-4300. Combe-Grenal 2, extract}

Ash (burned bone) from hearth at entrance to cave in Layer E2 at $2.5 \mathrm{~m}$ depth. Coll. 1964. Comment: treated as charred bone. As frequently happens, alkali soluble fraction gives higher apparent age (cf. el Kebarah, Haua Fteah C46, in Groningen IV). Sample contained many recent rootlets and it is not surprising that even "bone" fraction ( $\mathrm{GrN}$ 4300 ) is younger than $\mathrm{GrN}-4304$, above.

General Comment: 39,000 B.P. is only minimum age for culture. 


\section{La Rochette series, France}

Cave of La Rochette near Saint-Léon on R. Vézère $\left(45^{\circ} 01^{\prime} \mathrm{N}\right.$ Lat, $1^{\circ}\left(4^{\prime} \mathrm{E}\right.$ Long), Dordogne, has been re-excavated by $\mathrm{H}$. Delporte. Aurignacian and Mousterian culture layers are present (Delporte, 1962). Coll. and subm. 1964 by H. Delporte.

\section{GrN-4530. La Rochette 4, bone}

$28,860=300$ 26,910 в.с.

Bone collagen from Layer 4 with Aurignacian II industry statistically very similar to upper Aurignacian at Abri Cellier (Delporte, 1963). Comment: $\delta \mathrm{C}^{13}=-20.1 \%$.

\section{GrN-4529. La Rochette 5c, bone}

$28,420 \pm 320$

Bone Collagen from top $4 \mathrm{~cm}$ of $12-\mathrm{cm}$ thick Layer $5 \mathrm{c}$ in quadrants $\mathrm{Ft}$, Et in front of cave. Layer contains Aurignacian I industry somewhat more evolved than La Ferrassie Layer F (Delporte, 1963). Comment: as date is not older than that for La Rochette 4 it must be considered minimum. $\delta \mathrm{C}^{13}=-17.7 \%$.

\section{GrN-4362. La Rochette 7, extract}

$$
36,000=550
$$$$
\text { 34,050 в.C. }
$$

\section{GrN-4345. La Rochette 7, residue}

$\mathbf{3 0 , 7 0 0}=\mathbf{4 0 0}$

Bone-ash from Layer 7 containing Mousterian industry of type Abri Audi. Industry has marked blade character and gives impression of being late. Comment: material treated as charred bone. Large age diflerence between two fractions may be due to presence of undetected rootlets. Age of "bone fraction" (GrN-4362) nevertheless higher than oldest Upper Paleolithic dates from France.

\section{Abri Pataud series, France}

Extensive excavation by H. L. Movius at Abri Pataud $\left(44^{\circ} 56^{\prime} \mathrm{N}\right.$ Lat, $1^{\circ} 0^{\prime}$ E Long), Les Eyzies, Dordogne, has made samples of different materials available from all culture layers from Proto-Magdalenian to earliest Aurignacian (Movius 1966). Series presented here make comparison of dates from unburned bones with other material possible. Coll. and subm. 1961-1965 by H. L. Movius, Harvard Univ.

\section{GrN-3255. Abri Pataud 2, bone}

$19,650 \pm 300$

\section{GrN-4230. Abri Pataud 2, bone}

$20,810=170$

\section{GrN-4231. Abri Pataud 2, bone}

18,860 в.C.

Bone collagen from Layer 2, Lens 2 (Proto-Magdalenian). Comment: bone of GrN-3255 demineralized with EDTA by $\mathrm{H}$. de Waard. 
Compare dates for Proto-Magdalenian at Abri Pataud and LaugerieHaute Est in Groningen IV. Highest date for this culture so far is $21,980 \pm 250(\mathrm{GrN}-1876)$.

\section{GrN-4506. Abri Pataud 3, bone}

$22,780 \pm 140$ 20,830 в.C.

GrN-4721. Abri Pataud 3, bone

$23,010 \pm 170$

Bone collagen from Layer 3, Lens 2a (Perigordian VI). Comment: $\delta \mathrm{C}^{13}$ of $\mathrm{GrN}-4721=-20.4 \%$. Compare GrN-1892: $21,540 \pm 160$ for charred bone of same layer (Groningen IV).

GrN-4280. Abri Pataud 4, bone

$27,060 \pm 370$

25,110 в.C.

Bone collagen from Layer 4 (Perigordian Vc with Noailles burins). Comment: demineralized with EDTA by $\mathrm{H}$. de Waard.

GrN-4631. Abri Pataud 5, bone $21,780 \pm 215$ 19,830 B.C.

Bone collagen from front part of Layer 5 (not connected to rear part) with Perigordian IV industry (Gravette points). Comment: comparison with dates for Layer 5 , rear indicate result is too young.

GrN-4477. Abri Pataud 5, bone

$26,600 \pm 200$

24,650 в.C.

Bone collagen from Layer 5 , rear (Perigordian IV). Comment: $\delta \mathrm{C}^{13}$ $=-18.7 \%$.

GrN-4662. Abri Pataud 5, extract

$27,660 \pm 260$

GrN-4634. Abri Pataud 5, residue

25,710 в.c.

GrN-4634. Abri Pataud 5, residue

$28,150 \pm 225$

Charred bone from Layer 5, rear (Perigordian IV). Comment: pretreated as charred bone. Two fractions give same result within limits of statistical probability.

GrN-4531. Abri Pataud 7, bone

$31,800 \pm 310$

29,850 в.C.

Bone collagen from Layer 7 with Late Aurignacian industry with flattened, uncleft bone points. Comment: $\delta \mathrm{C}^{13}=-18.9 \%$.

\section{GrN-3105. Abri Pataud 7, charcoal \\ 27,350 в.c. \\ GrN-3117. Abri Pataud 7, charcoal \\ $32,800 \pm 450$ \\ 30,850 в.c. \\ GrN-3116. Abri Pataud 7, charcoal \\ $32,900 \pm 700$}

$29,300 \pm 450$

Large clump of fine charcoal from hearth in Layer 7 (Late Aurignacian). Coll. 1961 by H. de Waard. Comment: pretreatment performed by 
H. de Waard. GrN-3105 only pretreated with acid and obviously too young; GrN-3117 fully pretreated with acid and alkali; GrN-3116 is fraction which remained in colloidal suspension in alkali solution and was precipitated by salting. This material is considered the most reliable of whole series because charcoal can be pretreated more rigorously than burned or unburned bone. Preliminary results were published by H. L. Movius (1963), but final evaluation has shown them to have been in error by about $1000 \mathrm{yr}$. Best date for Aurignacian II of Layer 7 is 32,800 B.P. and not 34,000 B.P. as given there.

GrN-4326. Abri Pataud 11, extract

$32,000 \pm 800$ 30,050 в.c.

GrN-4309. Abri Pataud 11, residue $32,600 \pm 550$ 30,650 в.C.

Charred bone from Layer 11 with Intermediate Aurignacian industry with cleft base bone points. Comment: two fractions give same age within limits of statistics. Result seems slightly too young when compared with dates for Layer 7 .

\section{GrN-4327. Abri Pataud 12, extract}

GrN-4310. Abri Pataud 12, residue

Charred bone from Layer 12 (Early Aurignacian). Comment: as "bone fraction" gives higher age this figure is to be considered most reliable.

GrN-4719. Abri Pataud 12, bone

$33,260 \pm 425$ 31,310 в.c.

Bone collagen from Layer 12 (Early Aurignacian). Comment: compares well with charred bone from same layer (GrN-4327).

\section{GrN-4610. Abri Pataud 14, extract 31,350 в.c. \\ $34,250 \pm 675$ \\ GrN-4507. Abri Pataud 14, residue \\ 32,300 в.c.}

$33,300 \pm 760$

Charred bone from Layer 14 (Early Aurignacian). Comment: two fractions give same age within limits of uncertainty.

GrN-4720. Abri Pataud 14, bone

$33,330 \pm 410$ 31,380 в.c.

Bone collagen from Layer 14 with Early Aurignacian industry. Comment: within limits of uncertainty same result as for charred bone, above.

General Comment: from this series it appears that, in general, dates from unburned bones are as reliable as those from burned bones. Experience shows that reliability of dates from unburned bones depends on degree of preservation of collagen: where collagen is well preserved it is possible to extract younger contamination more completely and obtain 
satisfactory results. It is obvious that pretreatment was not always equally successful, especially in early stages of experimentation.

From this series a much more detailed estimate of the chronology of early Upper Paleolithic in France can be made than was hitherto available. The following dates can be deduced for the occupation at Abri Pataud:

$$
\begin{array}{lll}
\text { Aurignacian 0 } & -34,000 \text { в.P. } \\
\text { Aurignacian I } & -33,000 \text { B.P. } \\
\text { Aurignacian II } & -32,800 \text { B.P. } \\
\text { Perigordian IV } & -28,000 \text { в.P. } \\
\text { Perigordian VC } & -27,000 \text { в.P. } \\
\text { Perigordian VI } & -23,000 \text { в.P. } \\
\text { Proto-Magdalenian } & -22,000 \text { B.P. }
\end{array}
$$

Regarding beginning of Upper Paleolithic it must be noted that it has not yet been possible to obtain higher date than 34,000 B.P. in France. The youngest Mousterian has given dates of ca. 35,000 R.P. (cf. La Quina, above) and older. At present it therefore seems that transition occurred between these two figures. It is of course possible that dates are too young and, when more reliable material becomes available, slightly higher ages will be found, but for the present these results can be accepted for comparison with other regions.

\section{Laugerie-Haute Ouest series, France}

In $1959 \mathrm{~F}$. Bordes and Ph. Smith made a further excavation in W part of Paleolithic site at Laugerie-Haute (44 $58^{\prime} \mathrm{N}$ Lat, $0^{\circ} 57^{\prime} \mathrm{E}$ Long), near Les Eyzies, Dordogne; and Smith (1966) undertook a detailed invetigation of the ca. $1 \mathrm{~m}$ thick Solutrean layers. Burned bone samples from all layers subm. 1959 by F. Bordes.

GrN-4441. Laugerie-Haute 2, residue

$20,000 \pm 240$

GrN-4605. Laugerie-Haute 2, extract 18,050 в.c.

Burned bone from Layer 2; top of Upper Solutrean.

GrN-4442. Laugerie-Haute 5, residue

$19,870 \pm 190$ 17,920 в.с.

GrN-4495. Laugerie-Haute 5, extract

$19,600 \pm 140$

17,650 в.c.

$19,740 \pm 200$

Burned bone from Layer 5; transition Middle to Upper Solutrean.

GrN-4446. Laugerie-Haute 12a, residue

$\mathbf{2 0 , 8 1 0} \pm \mathbf{2 3 0}$

18,860 в.C.

GrN-4469. Laugerie-Haute 12a, extract

$20,160 \pm 100$ 18,210 в.c.

Burned bone from Layer 12a; top of Lower Solutrean. Comment: $\delta \mathrm{C}^{13}=-21.1 \%$ and $-21.3 \%$ respectively. 
GrN-4573. Laugerie-Haute 12d, extract 18,800 в.c.

Burned bone from Layer 12d; base of Lower Solutrean. Comment: $\delta \mathrm{C}^{13}=-21.9 \%$.

General Comment: all samples treated as for burned bone (Groningen IV) and both fractions measured where possible. Close correspondence of results for different fractions indicates negligible contamination. Whole Solutrean occupation apparently lasted less than $1000 \mathrm{yr}$-from ca. 20,800 B.P. to ca. 19,900 B.P. Date for Lower Solutrean at adjacent Laugerie-Haute Est, GrN-1888: 20,890 \pm 300 (Groningen IV) compares excellently with dates for same stage here (Layer 12).

\section{B. Other Countries}

\section{Broion cave series, Italy}

Systematic excavation in Broion cave $\left(45^{\circ} 27^{\prime} 58^{\prime \prime} \mathrm{N}\right.$ Lat, $11^{\circ} 33^{\prime} 56^{\prime \prime}$ E Long) in Mt. Berici ca. $10 \mathrm{~km} \mathrm{~S}$ of Vicenza has revealed succession of Mousterian and Upper Paleolithic culture layers (Leonardi, 1962). Coll. 1962 by A. Broglio; subm. 1965 by P. Leonardi, Inst. of Geol., Univ. of Ferrara.

\section{GrN-4637. Broion 1}

$46,400=1500$

\section{GrN-4638. Broion 2}

44,450 в.c.

$40,600=1200$

Two charcoal samples from Layer I, ca. $5 \mathrm{~m}$ depth in Great Hall of cave associated with Final Mousterian assemblage. Comment: higher age of Broion 1 is considered the more reliable date for culture.

\section{Salzofenhöhle series, Austria}

Salzofen cave $(2008 \mathrm{~m})$ near Bad Aussee $\left(47^{\circ} 36^{\prime} \mathrm{N}\right.$ Lat, $13^{\circ} 46^{\prime} \mathrm{E}$ Long), Styria has been systematically excavated by K. Ehrenberg over a number of years. Below limestone debris in red-brown "phosphate earth," containing large quantities of Ursus spelaeus bones, occurs culture layer with hearths and a few Mousterian-like artifacts. Geological dating is interglacial (cf. Ehrenberg, 1959). As large statistical uncertainty of GrN-761: $34.000 \pm 3000$ (Groningen III) does not exclude possibility of age exceeding 50,000 yr new samples were collected for analysis. Coll. and subm. 1959 by K. Ehrenberg, Meyrinkgasse 1, Wien-Mauer.

\section{GrN-2104. Salzofenhöhle b, humus fraction $\mathbf{2 4 , 6 5 0}$ B.c.}

Charred bone and wood excavated 1958/59 from culture layer in outer chamber. Comment: sample became contaminated with wadding which was laborously removed. Major portion dissolved in alkali and this fraction was measured. Result is therefore only minimum. 
GrN-4628. Salzofenhöhle c

Collagen from $120 \mathrm{~g}$ bone excavated 1959 from culture layer in outer chamber. Comment: result indicates that bear remains are indeed older than mid-Würm interstadials (Paudorf).

\section{Tata series, Hungary}

At Tata (ca. $47^{\circ} 40^{\prime} \mathrm{N}$ Lat, $18^{\circ} 10^{\prime} \mathrm{E} \mathrm{Long),} \mathrm{ca.} 70 \mathrm{~km} \mathrm{~W}$ of Budapest massive calcareous tufa has been deposited by an old thermal spring. A rich late Mousterian settlement-site was discovered by T. Kormos (1909) in a sandy loess lense intercalated in tufa. In $1958 \mathrm{~L}$. Vértes investigated an extension of site (Vértes et al., 1964). Assemblage contains high percentage $(23 \%)$ of bifacially worked artefacts and some workers (Hillebrand, Breuil) classified it as Proto-Solutrean (Szeletian). Prošek considers it immediate predecessor of Szeletian (Vértes, 1959). On basis of faunal and floral remains Vértes considers habitation to belong to an interstadial. Samples coll. and subm. 1959 by L. Vértes, Magyuar Nemzeti Múzeum, Budapest.

GrN-3023. Tata, charred bone

33,330 \pm 900 31,380 в.C.

Charred bone from culture layer in depression in older tufa covered by $8 \mathrm{~m}$ of younger tufa. Comment: extractable "bone fraction" measured. Date considered too young by submitter.

\section{GrN-2538. Tata, tufa}

$\mathbf{5 0 , 5 0 0}+\mathbf{3 0 0 0}$

Calcareous tufa (travertine) deposited by thermal spring taken from core at $3.0 \mathrm{~m}$ depth near settlement site, stratigraphically $2 \mathrm{~m}$ above culture layer. Comment: sample rinsed in acid before evolution of $\mathrm{CO}_{2}$ for measurement. Later, submitter suggested that sample was $1.5 \mathrm{~m}$ below culture layer to explain age difference with GrN-3023. Although freshwater limestone can be used for dating (Vogel, 1959; Münnich \& Vogel, 1959) the use of limestone deposited from a thermal spring is highly problematical because the original dissolved carbonate in the water may have had very low $\mathrm{C}^{14}$ content-especially if water was of deep-seated origin. Date may therefore be much too old.

\section{Érd series, Hungary}

At Érd (4720 $\mathrm{N}$ Lat, $18^{\circ} 50^{\prime} \mathrm{E}$ Long), $25 \mathrm{~km} \mathrm{SW}$ of Budapest a stratified Mousterian site has been excavated by Gábori a.o. Several habitation layers between ca. $2.2 \mathrm{~m}$ and $3.2 \mathrm{~m}$ have produced large amount of "Charentien" artefacts of type La Quina. Faunal remains indicate climatic change from humid to cold. Coll. and subm. 1964 by V. Gábori-Csánk, Budapesti Történeti Muzeum, Budapest. 


\section{GrN-4443. Érd 1}

$35,300 \pm 900$

GrN-4711. Érd 1, humus fraction

$39,350 \pm 830$

Charcoal from top of culture layer at $2.20 \mathrm{~m}$ depth.

\section{GrN-4444. Érd 2}

$44,300 \pm 1400$ it om of upper culture layer at $2.40 \mathrm{~m}$ depth Comment: it is strange that alkali soluble fraction of Erd 1 $(\mathrm{GrN}-4711)$ gave higher age than insoluble fraction. As assemblage in upper layer does not give impression of extremely long duration, 39,350 B.P. is more acceptable when compared with date for Érd 2. Discrepancy could be caused by $0.5 \%$ by weight of undetected recent rootlets. Age of ca. 39,000 B.P. is therefore proposed as minimum for level. Compare GrN-2526, La Quina 2: 35,250 \pm 530, for Final Mousterian which overlies "Charentien" at La Quina (Groningen IV).

\section{Molodova series, Ukraine}

Extensive excavations since 1956 at Molodova on Dniester R., Kelmenetsk dist., province of Chernovitz ( $48^{\circ} 30^{\prime} \mathrm{N}$ Lat, $26^{\circ} 00^{\prime} \mathrm{E}$ Long), have revealed succession of culture layers from Mousterian to Mesolithic. (Chernysh, 1962). The rich late Mousterian layer occurs some 14 to 18 $\mathrm{m}$ above IInd Dniester terrace in loam and below approx. $5 \mathrm{~m}$ of partly solifludially disturbed clay and approx. $5 \mathrm{~m}$ of loess and loess-loam (Ivanova, 1962). Coll. and subm. by Mrs. I. K. Ivanova, Acad. of Sci. of U. d. S. S. R., Moscow.

\section{GrN-3659. Molodova I}

Charcoal from hearth in oval dwelling space formed by mammoth bones at ca. $10 \mathrm{~m}$ depth at site Molodova I. In oval lay multitude of flint artifacts ascribed to late Mousterian (with Levalloisian technique). Probably younger than Lebenstedt (GrN-2083: 55,600 \pm 900, Groningen VI). Coll. 1961.

GrN-4017. Molodova V

Charcoal associated with same Late Mousterian at ca. $10 \mathrm{~m}$ depth at site Molodova V, $1.2 \mathrm{~km}$ from Molodova I. Coll. 1962.

General Comment: samples were too small to make more precise measurement. GrN-3659 proves settlement at least 44,000 yr and is thus older than oldest Upper Paleolithic elsewhere.

GrN-4121. Geulah Cave A, Israel

$42,000 \pm 1700$

Bone ash from ca. $3 \mathrm{~m}$ depth in Layer $\mathrm{B} 2$ in front of Geulah Cave, Mt Carmel (ca. $32^{\circ} 40^{\prime} \mathrm{N}$ Lat, $35^{\circ} 05^{\prime} 05^{\prime \prime} \mathrm{E}$ Long), Israel, associated with lower Levalloiso-Mousterian industry (Wreschner et al., 1960). Coll. 
and subm. 1962 by E. Wreschner, Haifa-Nava Saanan, Mendelistr. 19. Comment: pretreated as for charred bone and alkali-soluble fraction measuled (cf. Groningen IV). Many rootlets encountered and removed as far as possible. Date comparable to GrN-2729, Et Tabun C: 40,900 士 1000 (Groningen IV).

\section{GrN-4486. Haua Fteah C29, Libya}

$33,500 \pm 900$

Additional date to series for Haua Fteah $\left(32^{\circ} 47^{\prime} \mathrm{N}\right.$ Lat, $21^{\circ} 41^{\prime} \mathrm{E}$ Long) presented in Groningen IV. Sample consisted of scattered charcoal fragments from bottom of Layer XXI and upper half of Layer XXII shortly above transition from Mousterian to Dabba culture. Comment: sample just below C93, GrN-2550: 33,100 \pm 400 and lowest dated Upper Paleolithic level. Taking all dates into account, transition from Mousterian to Upper Paleolithic at site can be placed by interpolation at $38,000 \pm 1000$ B.P.

\section{GrN-4218. Arka 2, Hungary}

$13,230 \pm 85$

Hearth filling from $2.0 \mathrm{~m}$ depth in Block $\mathrm{m}$ at Eastern Gravettian site of Arka-Herzsarét $\left(48^{\circ} 30^{\prime} \mathrm{N}\right.$ Lat, $21^{\circ} 30^{\prime} \mathrm{E}$ Long), district BorsodAbauj-Zemplén, N. Hungary (Vértes, 1962). Coll. and subm. 1963. Comment: sample originally thought to be from same culture layer as GrN4038, Arka: 17,050 \pm 350 B.P. (Groningen V), but subm. has suggested possible assignment to upper culture layer (cf. Kretzoi and Vértes, 1965, p. 140).

\section{GrN-4869. 't Ronde, Netherlands}

Pinus charcoal from fireplace at depth $0.50 \mathrm{~m}$ in $\mathrm{B}$ horizon of soil profile at surface site of Upper Paleolithic Hamburgian culture at 't Ronde $\left(52^{\circ} 55^{\prime} \mathrm{N}\right.$ Lat, $6^{\circ} 15^{\prime} \mathrm{E}$ Long) near Elsloo, municipality of Ooststellingwerf, province of Friesland, excavated for Biologisch-Archaeologisch Instituut, Univ. of Groningen, by P. Houtsma, Waskemeer. Although fireplace was of same type as normally occurring in Mesolithic contexts there was chance of its being Paleolithic (ca. 12,000 в.c.). Coll. 1966; subm. by P. Houtsma. Comment: date proves that hearth is Mesolithic. Hamburgian site in neighborhood (Duurswoude II) was dated at $11,090 \pm 90(\mathrm{GrN}-1565$, erroneously published in Groningen IV as belonging to Tjonger culture). In latter case culture layer was situated below Upper Dryas sand dune; presence of charcoal must in this case be due to late Alleröd forest-fires, discussed in Groningen III (p. 3292). Many other anomalous dates from Paleolithic surface or near-surface sites in sandy areas of Netherlands and adjacent countries can be explained by either the very common occurrence of Mesolithic fireplaces or extensive forest-fires in late Alleröd times. Further examples are Hamburgian of Donderen, GrN-152: $6950 \pm 160$; Tjongerian of Een, GrN-236: $7030 \pm 140$ (Groningen I); Tjongerian of Nederweert, GrN908: $9555 \pm 110$ and Lommel, GrN-911: $7790 \pm 90$ (Groningen II) and 
Hamburgian of Deimern (below). On the other hand the same causes can make Neolithic and younger samples too old, as was clearly demonstrated in cases of GrN-051: $7865 \pm 240$ (see Groningen I) for Iron age urnfield and Anlo series (Groningen IV, p. 178-80). $\delta \mathrm{C}^{13}=-25.0 \%$.

\section{GrN-4653. Deimern, Germany}

$8160 \pm 60$

Charcoal from Hamburgian surface site at Deimern, Kreis Soltau, near Hanover (52 $24^{\prime} \mathrm{N}$ Lat, $9^{\circ} 44^{\prime} \mathrm{E}$ Long), coll. 1964 at depth 0.60 to $0.70 \mathrm{~m}$ below $\mathrm{B}$ horizon of soil profile by W. Nowothnig, Landesamt für Bodendenkmalpflege, Hanover. Expected age approx. 12,000 B.c. (Nowothnig, 1963). Subm. by A. Bohmers, Groningen. Comment: date is too young. Charcoal is apparently of Mesolithic age.

\section{GrN-4871. Waskemeer, Netherlands}

$11,150 \pm 190$

9200 B.C.

Charcoal concentration at depth of $1.20 \mathrm{~m}$ below surface, $0.30 \mathrm{~m}$ below Usselo horizon (Alleröd period) and associated with remains of Upper Paleolithic Tjonger culture at the Waskemeer $\left(53^{\circ} 5^{\prime} \mathrm{N}\right.$ Lat, $6^{\circ}$ $15^{\prime} \mathrm{E}$ Long) near Duurswoude, municipality of Opsterland, province of Friesland (Bohmers \& Houtsma, 1961). Because of stratigraphic position below Alleröd horizon date before ca. 11,400 was expected. However, earlier measurement for charcoal of this site had yielded 10,800 \pm 230 (GrN-607, Groningen II). Coll. 1951 and subm. by P. Houtsma. Comment: there is no significant deviation from earlier measurement nor from dates obtained on charcoal from Usselo layers elsewhere (see Groningen II, p. 3292-3; mean value after applying corrections mentioned in Groningen IV, 10,900 B.P.) Presence of charcoal below Usselo horizon is probably due to animal activity or cryoturbation. For further discussion of anomalous dates see above, sub 't Ronde.

\section{Stegerveld series, Netherlands}

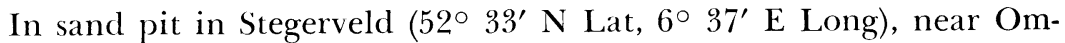
men, province of Overijssel (Butter, 1957) a section was found with two peat layers, separated by layer of sand, in upper part of which Mesolithic flint industry occurred. Pollen analysis (by F. P. Jonker) dates lower peat to Alleröd period, and upper peat to Late Boreal and Atlantic period. Flint-containing sand would date from Early Boreal period. Locally a Sub-boreal peat layer was found on top of Atlantic peat covered by dune sand. Coll. 1937 and subm. by J. Butter, Deventer, Netherlands.

GrN-2411. Stegerveld IV

Layer of gyttja below lower peat ("pre-Alleröd").

GrN-3004. Stegerveld III

Lower part of lower peat (Alleröd).
$11,600 \pm 130$

9650 B.C.

$11.300 \pm 90$

9350 в.c. 


\section{GrN-437. Stegerveld I}

Lower peat (Alleröd).

\section{GrN-2413. Stegerveld IV}

Finger-like lateral extension of uppermost part of lower peat (Preboreal).

\section{GrN-2461. Stegerveld VIII}

$9360 \pm 110$

Lower part of upper peat (Late Boreal).

\section{GrN-4056. Stegerveld V}

7410 в.c.

Charred wood in lower part of upper peat (Late Boreal).

\section{GrN-443. Stegerveld II}

$5370 \pm 190$

\section{GrN-2474. Stegerveld VII}

3420 в.C.

Two samples from upper part of upper peat (Atlantic).

General Comment: general agreement between pollen and radiocarbon dating. However, GrN-2413 does not follow stratigraphical sequence and according to pollen analysis it should be older. Pollen dating of GrN2461 (Late Boreal), too, is at variance with radiocarbon date, pointing to Early Boreal or Pre-boreal age. Anomaly probably due to interchange of both samples, coll. nearly 30 yr ago. Date of flint industry would thus be between $9410 \pm 110$ and $8500 \pm 100$ in agreement with pollen dating as Early Boreal.

\section{GrN-4673. Hahnentange, Germany}

$9060 \pm 50$

Charcoal from Mesolithic fireplace in clune area near Hahnentange (53 $7^{\prime} \mathrm{N}$ Lat, $7^{\circ} 34^{\prime} \mathrm{E}$ Long), Gemeinde Westrhauderfehn, Kreis Leer, Lower Saxony, excavated 1963 by Niedersächsische Landesstelle für Marschen- und Wurtenforschung, Wilhelmshaven. Quantity of accompanying flint industry was too small to permit more detailed chronological assessment. Subm. by W. Haarnagel, Wilhelmshaven. Comment: date points to relatively early stage in Mesolithic sequence. $\delta \mathrm{C}^{13}=-24.9 \%$.

\section{GrN-4870. Mettingen, Germany}

$8790 \pm 60$ 6840 B.c.

Charcoal from Mesolithic hearth on cover-sand ridge, some 100 $\mathrm{m} \mathrm{S}$ of Mittellandkanal, near Mettingen (52॰ $21^{\prime} \mathrm{N}$ Lat, $7^{\circ} 49^{\prime} \mathrm{E}$ Long), Kreis Tecklenburg, Nordrhein-Westfalen. Site yielded microlithic flint industry with burins and was therefore expected to be relatively early. Coll. 1966 and subm. by P. Houtsma. Comment: date is indeed earlier than most dates from Mesolithic fireplaces in Netherlands (e.g. Hatert, Oirschot, Rotsterhaule, Ermelo, in Groningen IV). $\delta \mathrm{C}^{13}=-22.2 \%$. 


\section{Beerzer Belten series, Netherlands}

Two samples from Mesolithic fireplaces in dune area Beerzer Belten (52 $31^{\prime} \mathrm{N}$ Lat, $6^{\circ} 27^{\prime} \mathrm{E}$ Long), municipality of Ommen, province of Overijssel (Butter, 1930). Coll. and subm. by J. Butter.

GrN-2418. Beerzer Belten I

$6660 \pm 90$ Coll. 1930 .

\section{GrN-4057. Beerzer Belten II}

Charcoal from fireplace at approx. $100 \mathrm{~m}$ distance from GrN-2418. Coll. 1962.

General Comment: GrN-2418 seems too young. GrN-4057 fits in general pattern of dates so far obtained from Mesolithic fireplaces.

\section{Wijster series, Netherlands}

During 1958-59 excavation of large settlement from 2nd-5th centuries A.D. (van Es, 1967) at Wijster (52 $51^{\prime} \mathrm{N}$ Lat, $6^{\circ} 31^{\prime} \mathrm{E}$ Long), municipality of Beilen, province of Drenthe, charcoal concentrations were found, that could either be Mesolithic, or so-called "Brandgruben," a type of grave expected to occur in Iron age. Depth 0.60 to $0.70 \mathrm{~m}$. Excavated for Biologisch-Archaeologisch Instituut, Univ. of Groningen by W. A. van Es (present address Rijksdienst voor het Oudheidkundig Bodemonderzoek, Amersfoort), who coll. and subm. samples.

GrN-4574. Wijster 518

GrN-4577. Wijster 581

GrN-4575. Wijster 836

GrN-4576. Wijster 841
$8400 \pm 80$ 6450 в.C.

$7980 \pm 60$ 5930 в.c.

$7660 \pm 50$ 5710 в.c.

A.D. 980

General Comment: apart from last sample, which is of Medieval age, charcoal concentrations appear to be Mesolithic fireplaces, of type and age common in area. Stray Mesolithic flints do occur at site. $\delta \mathrm{C}^{13}$ was $-24.5,-24.5,-23.8,-24.6^{c} / c c$ respectively.

\section{GrN-4325. Wartena, Netherlands}

$7450 \pm 80$

Charcoal from fireplace in concentration of Late Mesolithic flint artifacts on cover-sand below peat at Wartena $\left(53^{\circ} 9^{\prime} \mathrm{N}\right.$ Lat, $5^{\circ} 52^{\prime} \mathrm{E}$ Long), municipality of Idaarderadeel, province of Friesland. Depth 1.10 $\mathrm{m}$ below surface. Coll. 1964 and subm. by A. Bohmers. Comment: date according to expectation; in the area even typologically late Mesolithic industries are confined to Boreal period. $\delta \mathrm{C}^{13}=-25.9 \%$. 
II. NEOLITHiC OF EUROPE, N. AFRICA AND

THE NEAR EAST

A. Netherlands

\section{GrN-4544. Rijekholt, Netherlands}

Charcoal from basal part of gravel and chalk filling of Neolithic flint mine shaft (No. 3), excavated 1964 by W. M. Felder and collaborators, at Rijckholt (50 $48^{\prime} \mathrm{N}$ Lat, $5^{\circ} 44^{\prime} \mathrm{E}$ Long), province of Limburg. Depth approx. $6 \mathrm{~m}$. No datable archaeological material was found associated, but a contemporaneity with Michelsberg culture was expected. Subm. by H. T. Waterbolk. Comment: date proves contemporaneity of flint mine activities at Rijckholt with those at Spiennes, Belgium, dated as Lv-216: $5340 \pm 150$ and Lv-65: $5220 \pm 170$ (Louvain IV). At Spiennes Michelsberg pottery has been found associated with flint mining activities. $\delta \mathrm{C}^{13}=-25.4 \%$.

\section{GrN-4831. Stein, Netherlands}

$4780 \pm 60$

2830 B.C.

Charcoal found between quantity of cremated bones lying on stone pavement of Middle Neolithic burial vault at Stein $\left(50^{\circ} 57^{\prime} \mathrm{N}\right.$ Lat, $5^{\circ}$ 45' E Long), province of Limburg, excavated 1963 by P. J. R. Modclerman, Univ. of Leiden (Modderman, 1964). Burial vault, although unique in many respects, has some architectural and cultural contacts with megalithic tombs of Northern France, Hessen, Westfalia, and N. Germany-Denmark. Depth $0.60 \mathrm{~m}$. Subm. by P. J. R. Modderman. Comment: date proves archaeological conclusion. Chronological and geographical proximity of flint mines of Rijckholt (above) and Stein burials is interesting. $\delta \mathrm{C}^{13}=-26.2 \%$.

\section{GrN-4150. Drouwen, Netherlands}

Charcoal from pit in section through mound of megalithic Tomb

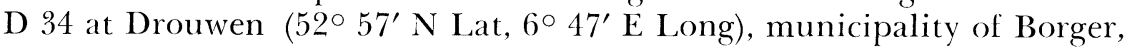
province of Drenthe. Pit could be same age as mound; expected age was therefore approx. 2700 B.c. Coll. and subm. by A. E. van Giffen, Groningen. Comment: date suggests that pit dates from pre-Roman Iron age.

\section{GrN-2362. Bargeroosterveld, Netherlands}

$3465 \pm 90$ D 46 at Bargeroosterveld, municipality of Emmen $\left(52^{\circ} 47^{\prime} \mathrm{N}\right.$ Lat, $6^{\circ}$ 53' E Long), Province of Drenthe. Expected age approx. 3000-2500 B.c. Subm. by A. E. van Giffen. Comment: date not that of original use of monument. Same applies to date of Drouwen (see above) and date GrN153: $3850 \pm 150$ of charcoal from megalithic tomb of Diever (Groningen I). Best date so far obtained for construction of megalithic tombs in 
Netherlands is GrN-226: $4590 \pm 80$ for a flat-grave below mound of megalithic Tomb D 32 at Odoorn (Groningen IV). Since flat-grave contained pottery of same type as generally found within chamber of tombs, there can not be large time difference between grave and construction of monument. This is confirmed by fact that settlement pit with pottery of Havelte phase of Funnel Beaker culture at Anlo has yielded date of $4420 \pm 55$ (GrN-1824, Groningen IV).

\section{Voorschoten series, Netherlands}

At Voorschoten (52॰ $8^{\prime} \mathrm{N}$ Lat, $4^{\circ} 25^{\prime} \mathrm{E}$ Long), province of South Holland, two sections were studied through a Neolithic settlement in a dune area. Sections comprise sequence of peaty and sandy layers with cultural remains of Vlaardingen culture (van Regteren Altena ct al., 1962/63), PFB culture (Protruding Foot Beaker culture) and Bell Beaker culture. Coll. 1965 by W. H. Metz; subm. by W. Glasbergen, Instituut voor Prae- en Protohistorie, Univ. of Amsterdam, Netherlands.

GrN-4906. Voorschoten 1

$4090 \pm \mathbf{5 0}$

Charcoal from basal part of layer with remains of Vlaardingen culture (Sec. A). Depth $1.20 \mathrm{~m}$ below surface $\left(-1.60 \mathrm{~m}\right.$ O.D.). $\delta \mathrm{C}^{13}=$ $-26.4 \%$.

GrN-4907. Voorschoten 5

$4080 \pm 70$

Charcoal from layer with remains of Vlaardingen culture (evolved stage, Sec. A). Depth $0.70 \mathrm{~m}$ below surface. $\delta \mathrm{C}^{13}=-25.9 \%$.

\section{GrN-4908. Voorschoten 6}

$3980 \pm 60$

2030 B.C.

Charcoal from layer with remains of Vlaardingen culture and $\mathrm{PFB}$ culture. (Sec. A) Depth 0.50 to $0.60 \mathrm{~m}$ below surface. $\delta \mathrm{C}^{13}=-25.6 \%$.

\section{GrN-4909. Voorschoten 18}

$2910 \pm 60$

Humic sand from layer in adjacent Sec. B with remains of Vlaardingen culture and PFB culture, stratigraphically above GrN-4908. Depth 0.20 to $0.40 \mathrm{~m}$ below surface. Comment: at least $1000 \mathrm{yr}$ younger than expected. $\delta \mathrm{C}^{13}=-27.8 \%$.

General Comment: dates from Vlaardingen culture are approx. 205 yr younger than those obtained at Vlaardingen (main occuption $4300 \pm$ 40, see Groningen IV, p. 178). Upper layers, with mixed remains of Vlaardingen and PFB cultures yield dates somewhat younger than those with pure remains of Vlaardingen culture. Series from Sec. A is terminus post quem for Bell Beaker culture (stage with hybrid beakers) dated at $3890 \pm 25$ at Vlaardingen (Groningen IV), remains of which occur stratigraphically immediately above Voorschoten 6. 
GrN-4201. Angelslo 72, Netherlands

2430 B.C.

Charcoal from settlement pit containing pottery, flint scrapers, etc. belonging to last stage of Funnel Beaker culture at Angelslo $\left(52^{\circ} 47^{\prime} \mathrm{N}\right.$ Lat, $6^{\circ} 53^{\prime}$ E Long), municipality of Emmen, province of Drenthe, excavated 1961 by J. D. van der Waals, Biologisch-Archaeologisch Instituut, Univ. of Groningen (van der Waals, 1964b). Pit is part of settlement and cemetery complex, from which so far only one other radiocarbon date could be obtained (GrN-2370: $4145 \pm 100$; Groningen IV). Depth 0.60 to $1.00 \mathrm{~m}$. Subm. by J. D. van der Waals. Comment: date does not significantly differ from GrN-2370. Preceding stage of Funnel Beaker culture has date of $4420 \pm 55$ (Anlo, GrN-1824; Groningen IV). $\delta \mathrm{C}^{13}=-25.3 \%$.

GrN-4154. Midlaren, Netherlands

$3960 \pm 70$

2010 B.c.

Wood (Alnus) from one of set of two unfinished one-piece disc wheels, found 1963 in small raised bog at Midlaren $\left(53^{\circ} 6^{\prime} \mathrm{N}\right.$ Lat, $6^{\circ}$ $40^{\prime}$ E Long), municipality of Zuidlaren, province of Drenthe. A study of dated Neolithic disc wheels (van der Waals, 1964a, see also Groningen IV, p. 180-1) has revealed their probable association with PFB culture. In present case earlier date possible, since remains of settlement of a relatively early stage of Funnel Beaker culture were found on edge of bog. Subm. by J. D. van der Waals. Comment: date agrees with those from other disc wheels and precludes an association with TRB finds. $\delta \mathrm{C}^{13}=-27.6 \%$.

\section{GrN-4155. Exloërveen, Netherlands}

$3900 \pm 60$

Wood from one-piece oak disc wheel, found 1928 or 1929 by peat diggers in raised bog of Exloërveen (52 $52^{\prime} \mathrm{N}$ Lat, $6^{\circ} 54^{\prime} \mathrm{E}$ Long), municipality of Odoorn, province of Drenthe. Depth $1.50 \mathrm{~m}$. Subm. by J. D. van der Waals. Comment: date does not differ significantly from the other Neolithic disc wheels found in Netherlands (van der Waals, 1964a). $\delta \mathrm{C}^{13}=-26.4 \%$.

GrN-4069. Onstwedde, Netherlands

$3970 \pm 65$

2020 B.c.

Wood (Taxus baccata) from core of a bow, found 1887 in peat at Stadskanaal, municipality of Onstwedde ( $53^{\circ} 2^{\prime} \mathrm{N}$ Lat., $6^{\circ} 52^{\prime} \mathrm{E}$ Long), province of Groningen, and preserved in Mus. of Assen (inventory number 1887/IX 3). Coll. by J. D. van der Waals; subm. by J. G.D. Clark, Univ. Mus. of Ethnology and Archaeol., Univ., Cambridge, U. K. Comment: see Clark (1963).

\section{Mander series, Netherlands}

Two prehistoric barrows were excavated at Mander, municipality of Tubbergen (52० $24^{\prime} \mathrm{N}$ Lat, $6^{\circ} 47^{\prime} \mathrm{E}$ Long), province of Overijssel, by C. C. W. J. Hijszeler, Rijksmuseum Twente, Enschede. Expected age approx. 1500 в.c. Coll. 1960 and subm. by excavator. 
GrN-2388. Mander C

Charcoal from primary tree coffin grave in Barrow I.

GrN-2982. Mander B

$3620 \pm 70$

1670 B.C.

Charcoal from secondary stone cist grave in Barrow I.

GrN-2969. Mander A

$3660 \pm 55$

1710 B.C.

Charcoal from Barrow II with primary stone cist grave.

General Comment: dates are somewhat older than expected. Both stone cists appear to be contemporaneous.

\section{GrN-4198. Hoog-Buurlo, Netherlands}

$1350 \pm 70$

Charcoal from pit found at distance of $1.00 \mathrm{~m}$ of flat grave with cremated bones and two Bell Beakers of Veluwe type, and thought to be contemporary with it at Hoog-Buurlo (52॰ $9^{\prime} \mathrm{N}$ Lat, $5^{\circ} 51^{\prime} \mathrm{E}$ Long), municipality of Apeldoorn, province of Gelderland. Expected age approx. 1600 B.c. Depth 0.80 to $1.10 \mathrm{~m}$. Coll. 1962 and subm. by J. D. van der Waals. Comment: see van der Waals (1964); date points to Medieval age of pit. $\delta \mathrm{C}^{13}=-25.6 \%$.

\section{GrN-4070. Heemstede, Netherlands}

$3500 \pm 100$

Wood (Taxus baccata) from core of a bow, found at de Zilk (52० $15^{\prime} \mathrm{N}$ Lat, $4^{\circ} 30^{\prime} \mathrm{E}$ Long), municipality of Noordwijkerhout, province of South Holland. Coll. by J. D. van der Waals, subm. by J. G. D. Clark, Cambridge, U. K. Comment: see Clark (1963).

\section{B. Other Countries}

\section{Cayönü series, Turkey}

Aceramic Neolithic site of Çayönü Tepesi $\left(38^{\circ} 14^{\prime} \mathrm{N}\right.$ Lat, $39^{\circ} 3^{\prime} \mathrm{E}$ Long), near Ergani, Diyarbakir Vilayet, Turkey, was excavated by R. J. Braidwood for Joint Prehistoric Project, Istanbul Univ. and Oriental Inst., Univ. of Chicago. Samples are from preceramic horizon. Typologically site is roughly similar to Jarmo. Coll. 1964 by A. J. Jelinek; subm. by R. J. Braidwood.

GrN-4458. Çayönü K-12, riverside cut

$9520 \pm 100$

Charcoal from cultural fill in Unit 12, Level $\mathrm{T} / 2$ (cut on riverside, behind stone pavement). $\delta \mathrm{C}^{13}=-24.5 \%$.

GrN-4459. Çayönü K-b \& g, 4-5

$9200 \pm 60$

Charcoal from cultural fill in Unit 6 \& 9, Level 4 to 5 (upper trench). $\delta \mathrm{C}^{13}=-24.7 \%$. 
General Comment: for Levels 4-5 there are two slightly different dates from Michigan, M-1609: 8790 \pm 250 and M-1610: 8570 \pm 250 (unpublished). Dates tend to substantiate choice of earlier cluster of radiocarbon dates for Jarmo site (ca. 6750 B.c.) (Braidwood and Howe, 1960).

\section{Bouqras series, Syria}

Pre-pottery Neolithic site of Bouqras (35 $3^{\prime} \mathrm{N}$ Lat, $40^{\circ} 28^{\prime} \mathrm{E}$ Long), $40 \mathrm{~km} \mathrm{SE}$ of Deir-ez-Zor, Syria. Excavated 1965 by W. J. van Liere and H. de Contenson for Natl. Mus. of Antiquities, Damascus (de Contenson \& Van Liere, in press). Samples from Level I (bottom) and Level II were collected by S. Bottema and W. van Zeist, those from Level I (top) and Level III by W. J. van Liere and H. de Contenson. Submitters W. J. van Liere, Damascus, and W. van Zeist, Univ. of Groningen, Netherlands.

GrN-4818. Bouqras, Level I bottom

$8140 \pm 60$

Scattered charcoal fragments in hearth, Sq. B9, depth $4.30 \mathrm{~m}$, prepottery Neolithic. $\delta \mathrm{C}^{13}=-25.8 \%$.

\section{GrN-4852. Bouqras, Level I top}

$8240 \pm 100$

Scattered charcoal fragments in hearth, Sq. A9, depth $3.30 \mathrm{~m}$, prepottery Neolithic. $\delta \mathrm{C}^{13}=-26.0 \%$.

\section{GrN-4819. Bouqras, Level II}

$7960 \pm 55$

Scattered charcoal fragments in hearth, Sq. A9, depth $1.70 \mathrm{~m} . \delta \mathrm{C}^{13}$ $=-26.1 \%$.

\section{GrN-4820. Bouqras, Level III}

$7840 \pm 60$ 5990 B.c.

Scattered charcoal fragments in hearth, Sq. B9, depth $0.40 \mathrm{~m}$, Neolithic with pottery, resembling early stages in Çatal Hüyük and northern Svria. $\delta \mathrm{C}^{13}=-25.8 \%$.

General Comment: GrN-4820 does not differ significantly from GrN4819. According to W. J. van Liere, attribution of hearth to potterycontaining top layers of tell was beyond all doubt; date should therefore be acceptable. Compare dates from Çatal Hüyük (Pennsylvania VIII).

\section{Ramad series, Syria}

Pre-pottery Neolithic site of Ramad (33 $27^{\prime} \mathrm{N}$ Lat, $36^{\circ} 5^{\prime} \mathrm{E}$ Long), $15 \mathrm{~km} \mathrm{SW}$ of Damascus, Syria. Excavated 1963 and 1965 by W. J. van Liere and H. de Contenson for Natl. Mus. of Antiquities, Damascus (de Contenson \& van Liere, 1964 and in press). 1963 samples were collected and submitted by W. J. van Liere, Damascus, those from 1965 excavation by S. Bottema and W. van Zeist. 
GrN-4428. Ramad, Square C8, 5-10 m

$$
8200 \pm 80
$$

Charcoal pieces in cultural fill in Sq. C8, depth $5.10 \mathrm{~m}$, pre-potters Neolithic without "vaisselle blanche." Coll. 1963. $\delta \mathrm{C}^{13}=-25.1 \%$.

\section{GrN-4821. Ramad, Level I}

$\mathbf{8 0 9 0} \pm \mathbf{5 0}$ depth $4.05 \mathrm{~m}$, pre-pottery Neolithic without "vaisselle blanche." Coll. 1965. $\delta \mathrm{C}^{13}=-23.9 \%$.

GrN-4427. Ramad, Square C8, $2.50 \mathrm{~m}$

Charcoal pieces in cultural fill in Sq. C8, depth $2.50 \mathrm{~m}$, pre-pottery Neolithic with "vaisselle blanche." Coll. 1963. $\delta C^{13}=-23.7 \%$.

\section{GrN-4822. Ramad, Level II}

$7900 \pm 50$ Neolithic with "vaisselle blanche." Coll. 1965.

GrN-4426. Ramad, Square H10, $0.50 \mathrm{~m}$

Charcoal pieces in cultural fill in Sq. H10, depth $0.50 \mathrm{~m}$. Pre-pottery Neolithic with plastered skulls. Coll. 1963. $\delta C^{13}=-24.4 \%$ c

GrN-4823. Ramad, Level III

Scattered charcoal fragments in pit, in Sq. C8, depth $1.65 \mathrm{~m}$. Neolithic with pottery, showing resemblance to the "Néolithique Moyen" of Byblos. $\delta \mathrm{C}^{13}=-25.2 \%$.

General Comment: samples from deepest strata (GrN-4428, -4821) are significantly older than those of middle strata (GrN-4427, -4822), but that from pottery containing pits in top of tell (GrN-4823) appears to be no younger. The charcoal in these pits, however, may be derived from older layers. Sample GrN-4426, although from top layers of tell, was accompanied by lithic material showing resemblance to that of deepest layers elsewhere in the tell.

\section{GrN-4145. Argissa 06, Greece}

$7500 \pm 90$

5550 B.c.

Charcoal from burnt post of early ceramic house found during excavation of Argissa Magula, near Larissa (39॰ 38' N Lat, $22^{\circ} 28^{\prime} \mathrm{E}$ Long), Thessaly, Greece (Milojčić, 1959), excavated by V. Milojčić, Institut für Ur- and Frühgeschichte, Univ. of Heidelberg, Germany, who subm. sample. Depth $8 \mathrm{~m}$, Level XXVIII b. Comment: for further dates from Argissa, see below, sub Bronze Age. GrN-4145 can be compared with dates from Elateia, GrN-2973: $5530 \pm 70$ B.c. (Groningen IV) and Nea Nikomedeia, Q-655: $6230 \pm 150$ в.C. (Cambridge V). $\delta \mathrm{C}^{13}=-24.9 \%$. 
GrN-4386. Chenachane, Algeria

$$
6580 \pm 50
$$

4630 B.c.

Charcoal from Neolithic culture layer in dry cave Chenachane $\left(25^{\circ}\right.$ $2^{\prime} \mathrm{N}$ Lat, $4^{\circ} 20^{\prime} \mathrm{W}$ Long), Massif des Eglabs, western Sahara, excavated 1950 by G. de Beauchêne, Musée de l'Homme, Paris. Neolithic differs from "Néolithique de tradition capsienne" by absence of geometrical microliths. It contains arrowheads, pottery, quernstones, ocher, and ornaments made from ostrich egg shells. Fauna contains elephant and warthog, which now occur much further south. Excavator considers this Neolithic as earlier than 3500 B.c., the mean date for Neolithic of Central Sahara (Faure and Hugot, 1964). Subm. by A. Bohmers. Comment: date confirms excavator's views. $\delta \mathrm{C}^{13}=-25.0 \%$.

\section{Lautereck series, Germany}

At Lautereck (48 20 $0^{\prime} \mathrm{N}$ Lat, $9^{\circ} 34^{\prime} \mathrm{E}$ Long), on upper Danube, Gemeinde Lauterach, Kreis Ehingen, Baden-Württemberg, a rock shelter was excavated by W. Taute, Institut für Vor- und Frühgeschichte, Univ. of Tübingen (Taute, in press). Site contains upper Mesolithic, Early Neolithic (Bandkeramik), Middle Neolithic (Aichbühl), Late Neolithic (Schussenried) and Tumulus Bronze Age culture layers. Coll. 1963 and subm. by excavator.

GrN-4667. Lautereck E

$6440 \pm 45$

Scattered charcoal fragments from aceramic culture layer with flint and bone industry of probably Late Mesolithic age. Depth 2.65 to $2.95 \mathrm{~m}$. $\delta \mathrm{C}^{13}=-25.4 \%$.

\section{GrN-4750. Lautereck D}

$6140 \pm 45$

Scattered charcoal fragments from culture layer with linear pottery (possibly "ältere Linienbandkeramik"). Depth 2.40 to $2.60 \mathrm{~m}$. $\delta \mathrm{C}^{13}=$ $-25.3 \%$.

GrN-4666. Lautereck C

Scattered charcoal fragments from culture layer with pottery of Aichbühl style (Middle Neolithic). Depth 2.20 to $2.40 \mathrm{~m}$. $\delta \mathrm{C}^{13}=-25.4 \%$. General Comment: dates in agreement with archeological expectation. Of great interest is apparent continuity of habitation of site during Mesolithic-Neolithic transition.

\section{Bylany series, Czechoslovakia}

Large Bandkeramik settlement of Bylany near Kutna Hora $\left(49^{\circ} 58^{\prime}\right.$ N Lat, $15^{\circ} 18^{\prime}$ E Long), Bohemia, excavated by Dr. B. Soudsky, Archeol. Inst. of Czechoslovakian Acad. of Sci., Prague (Soudsky, 1966). Subm. by excavator. 
GrN-4752. Bylany 501-2

$6170 \pm 45$

Charcoal from Pit 501, Layer 2, belonging to pre-optimal stage of middle degree of linear pottery (Bylany Violet I phase). Expected age approx. 4000 в.c.

\section{GrN-4754. Bylany 687-B}

$6270 \pm 65$ 4320 в.c.

Charred grain from Pit 687 , Part B, belonging to post-optimal stage of middle degree of linear pottery (Bylany Light-Green phase). Expected age approx. 3600 B.C. $\delta \mathrm{C}^{13}=-24.6 \%$

\section{GrN-4755. Bylany 441}

$6180 \pm 45$

Charcoal from Oven 441, belonging to latest degree (Sarkatype) of linear pottery (Bylany Brown II or III phase). Expected age approx. 3000 в.С. $\delta \mathrm{C}^{13}=-25.7 \%$

\section{GrN-4751. Bylany 512-4}

$5810 \pm 65$

Charcoal from Pit 512, Layer 4, containing stroked pottery ("Stichbandkeramik"). Expected age approx. 2600 в.с. $\delta \mathrm{C}^{13}=-26.3 \%$.

\section{GrN-4753. Bylany 544 B}

$9470 \pm 55$

7520 в.C.

Charcoal from Pit 544, Part B, belonging to late Lengyel horizon. Expected age approx. 2400 в.c. $\delta \mathrm{C}^{13}=-26.1 \%$.

General Comment: no explanation for anomalous age of GrN-4753. GrN-4751 agrees with GrN-4832: $5780 \pm 85$ for same cultural stage at Hienheim (below), Zwenkau-Harth (Bln-66: $5900 \pm 100$; Berlin I), Žalany (Bln-240: $5881 \pm 100$; Berlin II). Bandkeramik dates do not show age differences expected by excavator. They do agree, however, with numerous dates of Bandkeramik culture, obtained in Netherlands (Groningen IV, p. 176) and elsewhere (e.g. Berlin I and II).

\section{Hienheim series, Germany}

Neolithic settlement at Hienheim (48 $53^{\prime} \mathrm{N}$ Lat, $11^{\circ} 45^{\prime} \mathrm{E}$ Long), Kreis Kelheim, Bavaria, was excavated by P.J.R. Modderman, Leiden. Both samples consisted of scattered charcoal fragments in refuse pits in loess soil. Coll. 1965 and subm. by excavator.

GrN-4830. Hienheim 68

$\mathbf{5 9 1 0} \pm \mathbf{5 0}$

Charcoal from pit containing sherds attributed to "mittlere Linienbandkeramik." Depth 0.30 to $0.50 \mathrm{~m}$. $\delta \mathrm{C}^{13}=-24.9 \%$.

GrN-4832. Hienheim 108

$5780 \pm 85$ 3830 в.c.

Charcoal from pit containing typical "Stichbandkeramik" sherds. Depth $0.70 \mathrm{~m}$. 
General Comment: GrN-4830 is somewhat younger than most Bandkeramik dates so far obtained. GrN-4832 agrees with that from same cultural stage at Bylany (above, GrN-4751: $5810 \pm 65$ ).

\section{GrN-4674. Spiennes, Belgium}

$5420 \pm 75$

3470 B.C.

Ciharcoal from hearth No. 2431" belonging to stage Spiennes I (Precampignian) at "Camp à Cayaux" near Spiennes, in vicinity of Mons $\left(50^{\circ} 28^{\prime} \mathrm{N}\right.$ Lat, 3० $57^{\prime} \mathrm{E}$ Long) (Verheyleweghen, 1963), excavated by the late J. Verheyleweghen, Bruxelles, subm. by A. Bohmers and H. T. Waterbolk. Comment: date proves contemporaneity of late Precampignian with Early Neolithic cultures of western Europe. Should be compared with two Louvain dates from flint mines in same area (Lv-65: $5220 \pm 170$ and Lv-216: $5340 \pm 150$; Louvain II and IV) and clate from flint mine at Rijckholt (GrN-4544; $5070 \pm 60$, above).

\section{Niederwil series, Switzerland}

Neolithic bog settlement excavated 1962 and 1963 at Niederwil,

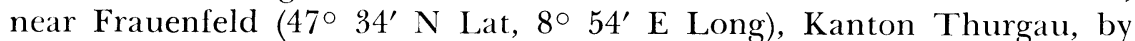
H. T. Waterbolk and collaborators (Waterbolk \& van Zeist, in press). Settlement belongs to Pfyn culture (Driehaus, 1960); it contained series of successive wooden floors pressed down in underlying gyttja. Coll. and subm. by H. T. Waterbolk and W. van Zeist.

\section{GrN-4203. Niederwil 180}

$4990 \pm 60$

Charred wheat (Triticum compactum) from 6th floor of House II. $\delta \mathrm{C}^{13}=-25.9 \%$.

\section{GrN-4202. Niederwil 107}

$4750 \pm 60$

Charred wheat (Triticum compactum) from 10th floor of House II. $\delta \mathrm{C}^{13}=-25.1 \%$.

\section{GrN-4204. Niederwil 689}

$4750 \pm 60$ $\delta \mathrm{C}^{13}=-24.9 \%$.

General Comment: GrN-4202 and 4203 follow stratigraphic order; GrN4204 was expected to be older; dating of further samples is postponed until after completion of dendrochronological analysis. Niederwil dates can be compared with those from Thayngen (Pfyn culture influenced by Michelsberg culture) as for example GrN-239: $4735 \pm 100$ (Groningen I) and B-43: $4690 \pm 130 ; \mathrm{B}-44: 4690 \pm 180 ; \mathrm{B}-45: 4780 \pm 130$ (Bern I).

\section{Frágoas series, Portugal}

Megalithic tomb (passage grave) of Frágoas, Concelho Vila Nova de Paiva (40 $51^{\prime} \mathrm{N}$ Lat, $7^{\circ} 43^{\prime} \mathrm{W}$ Long), district Viseu, province of Beira. Coll. 1964 by L. Ribeiro and V. Leisner; subm. by V. Leisner, Travessa de Dom Vasco 4-I-E, Lisboa, Portugal. 


\section{GrN-4924. Frágoas 1}

Charcoal from deepest stratum of archaeological layer, overlying weathered granite rocks, in chamber. Depth 1.30 to $1.40 \mathrm{~m}$ below exterior level. $\delta \mathrm{C}^{13}=-26.5 \%$.

\section{GrN-4925. Frágoas 3}

$4610 \pm 50$

Charcoal from black organic earth (archaeological layer) in chamber. Depth 1.00 to $1.30 \mathrm{~m}$ below exterior level. $\delta \mathrm{C}^{13}=-26.7 \%$.

General Comment: in general agreement with dates obtained from passage graves elsewhere in western Europe.

\section{Videlles series, France}

Sections in rock fissure No. 5 at les Roches, commune de Videlles (48 $35^{\prime} \mathrm{N}$ Lat, $2^{\circ} 30^{\prime}$ E Long), Dept. Seine-et-Oise, excavated 1962-3 by G. Bailloud, 29 rue Descombes, Paris. Late Danubian remains are separated by sterile layer from sequence belonging to Late Neolithic SeineOise-Marne culture (cf. Bailloud, 1959). Bronze Age layers cover S.O.M. remains. Subm. by A. Bohmers, Groningen. Expected age 2000-1500 в.c.

GrN-4676. Videlles II

$$
4500 \pm 50
$$

Charcoal from lower part of S.O.M. layer. Depth approx. $1.50 \mathrm{~m}$. $\delta \mathrm{C}^{13}=-23.4 \%$

\section{GrN-4675. Videlles I}

$4500 \pm 60$

Charcoal from upper part of S.O.M. layer. Depth approx. $1.20 \mathrm{~m}$. $\delta \mathrm{C}^{13}=-24.6 \%$.

General Comment: dates are somewhat older than expected.

\section{GrN-4065. Homolka, Czechoslovakia}

$4260 \pm 70$

2310 B.C.

Charcoal from burnt hut post at Homolka $\left(50^{\circ} 4^{\prime} \mathrm{N}\right.$ Lat, $14^{\circ} 0^{\prime} \mathrm{E}$ Long), $25 \mathrm{~km} \mathrm{~W}$ of Prague, Bohemia. Settlement belongs to Eneolithic Rivnač culture. Some evidence points to survival of site into ProtoUnětice or Pre-Classical Unětice times. Expected age 1800-1700 B.c. Subm. by R. W. Ehrich, Brooklyn College, New York. Comment: date is much older than expected. Further measurements are needed for Eneolithic sites in Central Europe.

III. BRONZE AGE AND LATER OF ELROPE

AND THE NEAR EAST

\section{A. Netherlands}

\section{GrN-4885. Hilversum, Netherlands}

Charcoal from burnt heavy beam in central cremation grave of barrow No. 6 with ditch and timber circle (Bursch, 1935) at Hilversum 
(52० 13' N Lat, $5^{\circ} 10^{\prime} \mathrm{E}$ Long), province of North Holland, excavated 1934 by F. C. Bursch and 1965 by A. E. van Giffen and J. A. Bakker. Barrow probably belongs to Hilversum culture. Coll. 1934 by F. C. Bursch; subm. 1966 by J. A. Bakker, Instituut voor Prae- en Protohistorie, Univ., Amsterdam. Comment: date is somewhat younger than other dates from Hilversum culture, such as GrN-1051: $3480 \pm 65$ and GrN-1029: $3330 \pm 40$ (Toterfout-Halve Mijl, Groningen III), but it agrees with a date from Vogelenzang (GrN-2997: $3140 \pm 70$; Groningen IV). For further discussion of Bronze age radiocarbon dates see Waterbolk (1964).

\section{GrN-4243. Zwaagdijk, Netherlands}

Charcoal from silting of ditch belonging to Bronze age settlement

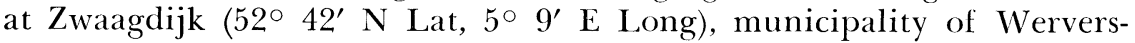
hoof, province of North Holland, excavated by P. J. R. Modderman, Leiden (Modderman, 1966). Coll. and subm. by excavator. Comment: a flatgrave in immediate neighborhood of settlement yielded bronze rapier dating from 1300-1100 B.c. (Butler, 1966). Modderman (1966) uses preliminary value $3310 \pm 60$ as result of GrN-4243. Present value was obtained after applying all corrections. $\delta \mathrm{C}^{13}=-25.8 \%$.

\section{Elp series, Netherlands}

Bronze age settlement near Elp (52 $54^{\prime} \mathrm{N}$ Lat, $6^{\circ} 38^{\prime} \mathrm{E}$ Long), municipality of Westerbork, province of Drenthe (Waterbolk, 1964) was excavated 1962 by $\mathrm{H}$. T. Waterbolk. It was found adjacent to Middle Bronze age timber circle barrow and contained 6 successive farm-steads each consisting of a three-aisled long house and a number of accompanying sheds and barns. Subm. by excavator.

GrN-4171. Elp 69

$3230 \pm \mathbf{8 0}$

Charred grain from refuse pit. $\delta \mathrm{C}^{13}=-23.2 \%$.

\section{B.C.}

GrN-4170. Elp 60

$3000 \pm 70$

Charcoal from refuse pit. $\delta \mathrm{C}^{13}=-27.1 \%$.

1050 B.C.

GrN-4172. Elp 94

$2980 \pm 60$

1030 B.c.

Charcoal from refuse pit. $\delta \mathrm{C}^{13}=-27.5 / / c$.

\section{GrN-4173. Elp 97}

$2860 \pm 60$

Charcoal from refuse pit. $\delta \mathrm{C}^{13}=-27.8 \%$.

910 B.C.

General Comment: to the series should be added GrN-2881: $2755 \pm 65$ (Groningen IV). Dates attest duration of settlement of some $400 \mathrm{yr}$, and gradual replacement of farm-stead towards the barrow, which appears to be contemporary with first stage of settlement. See Waterbolk (1964). 


\section{Vasse series, Netherlands}

Late Bronze age long house was excavated at Vasse, municipality of Tubbergen (52 $24^{\prime} \mathrm{N}$ Lat, $6^{\circ} 47^{\prime} \mathrm{E}$ Long), province of Overijssel, by C. C. W. J. Hijszeler, Rijksmuseum Twente, Enschede. Coll. 1960 and subm. by excavator. Expected age approx. 500 B.c.

GrN-2978. Vasse I

$3170 \pm 55$

Charcoal from pit I.

1220 B.C.

GrN-2983. Vasse II

$3020 \pm 70$

Charcoal from Pit II.

General Comment: dates older than expected. House (unpub.) appears to be contemporary with Elp (see above) and Deventer (GrN-955: 3060 \pm 70 and GrN-967: $3130 \pm 70$; Groningen III) settlements.

\section{Emmererfscheidenveen series, Netherlands}

Two prehistoric trackways in large raised bog $\mathrm{E}$ of Emmen $\left(52^{\circ} 48^{\prime}\right.$ $\mathrm{N}$ Lat, $7^{\circ} 0^{\prime} \mathrm{E}$ Long), province of Drenthe, were investigated by W. A. Casparie, Biologisch-Archaeologisch Instituut, Univ., Groningen. Subm. by investigator.

$\mathbf{3 1 2 0} \pm \mathbf{5 0}$

GrN-4149. Emmererfscheidenveen, S foot-path, 11170 B.c.

$\mathbf{3 1 4 5} \pm \mathbf{5 5}$

GrN-4342. Emmererfscheidenveen, S foot-path, 21195 B.c.

Outer year-rings of oak plank of Southern foot-path at transition of Upper and Lower Sphagnum peat. Depth $1.25 \mathrm{~m}$. Expected age 0 to 500 B.c. Coll. 1961. Comment: GrN-4342 is new sample from same trackway. $\delta \mathrm{C}^{13}=-27.8 \%$.

GrN-4147. Emmererfscheidenveen, wattled track 170 B.c.

Wood from unique trackway made of wattling. Depth 0.60 to 0.90 $\mathrm{m}$ below present bog-surface. Situated within Upper Shagnum peat. Expected age A.D. 100-300.

General Comment: both trackways are considerably older than expected on basis of pollen datings by van Zeist (1955, p. 47-9). In light of now much larger pollen evidence for area, dates are acceptable. Foot-path appears to date from Bronze age. It does not differ much in age from wooden sanctuary of Bargeroosterveld in same area of raised bog $(\mathrm{GrN}$ 1552: $3240 \pm 65$; Groningen IV). Other track appears to date from preRoman Iron age. It is of about same age as Valthe trackway (GrN-1085: $2295 \pm 50$; Groningen III).

\section{Goirle series, Netherlands}

Late Bronze age ring-ditch urnfield "Hoogeīnd" at Goirle $\left(51^{\circ} 30^{\prime}\right.$ N Lat, $50^{\circ} 0^{\prime}$ E Long), province of North Brabant, excavated 1965 by 
G. J. Verwers, Instituut voor Prehistorie, Univ., Leiden. Excavated part of cemetery contains system of 8 parallel, oblong ditches, surrounded by circular ditches. Expected age 1000-800 B.c. Earlier excavations published by Remouchamps (1926). Coll. and subm. by excavator.

\section{GrN-4919. Goirle 3}

Charcoal in silting of oblong ditch. Depth 0.40 to $0.50 \mathrm{~m}$. $\delta \mathrm{C}^{13}=$ $-24.8 \%$.

\section{GrN-4920. Goirle 8}

Charcoal in posthole connected with oblong ditch No. 3. Depth 0.40 to $0.70 \mathrm{~m}$. $\delta \mathrm{C}^{13}=-26.4 \%$.

\section{GrN-4921. Goirle 29}

$\mathbf{2 8 7 0} \pm \mathbf{5 0}$

Charcoal in silting of circular ditch. Depth 0.40 to $0.50 \mathrm{~m}$. $\delta \mathrm{C}^{13}=$ $-25.0 \%$.

General Comment: dates according to expectation; they prove contemporaneity of circular and oblong ditch. An oblong ditch of same type at Hilvarenbeek was dated as GrN-1674: $2850 \pm 60$ (Groningen IV).

\section{GrN-4368. Ezinge, Netherlands}

$2300 \pm 65$

Wood from post left in sub-soil after excavation (ca. 1930) of dwelling mound of Ezinge (53 $19^{\circ} \mathrm{N}$ Lat, $6^{\circ} 26^{\prime} \mathrm{E}$ Long), province of Groningen (van Giffen, 1936). Post belongs to first house, built on site. Expected age approx. 300 B.c. Re-excavation 1964; subm. by A. E. van Giffen, Groningen. Comment: date according to expectation. Settlement represents a somewhat younger stage than found at German site of Hatzum with dates from $2460 \pm 50(\mathrm{GrN}-4344)$ to $2340 \pm 35$ (GrN4668 , below). $\mathrm{C}^{13}=-25.1 \%$.

\section{Grijpskerk series, Netherlands}

Iron age site at Grijpskerk ( $53^{\circ} 16^{\prime} \mathrm{N}$ Lat, $6^{\circ} 18^{\prime} \mathrm{E}$ Long), province of Groningen, excavated by A. E. van Giffen. Culture layer was situated on sandy outcrop in clay landscape and covered by marine clay with Scrobicularia shells. Expected age 200 B.c. to A.D. 100. Coll. 1963 and subm. by excavator.

\section{GrN-4110. Grijpskerk A}

$2180 \pm 65$

Organic material from culture layer.

230 B.C.

\section{GrN-4151. Grijpskerk B}

$2560 \pm 80$

610 B.C.

GrN-4222. Grijpskerk B bis

$2510 \pm 80$

560 в.C.

Chaff (or dung) tempered pottery sherds. Comment: two parts of same sample, pretreated independently. $\delta \mathrm{C}^{13}=-27.0 \%$. 
GrN-4221. Grijpskerk C

$1150 \pm 80$

Scrobicularia shells in overlying marine clay. No correction applied for $\delta \mathrm{C}^{13}=-4.2 \%$.

General Comment: only GrN-4110 can be accepted as dating the site. GrN-4151 and -4222 give age a few centuries too high. This may be due to original carbonaceous content of clay used for making pottery. In another case (settlement 1st-2nd century A.D. at Vries) good agreement was found between the archaeological date and radiocarbon date obtained from chaff tempered sherds (GrN-793: $1720 \pm 60$; Groningen IV). In this case pottery was from boulder clay which has no organic content.

\section{Valkenburg series, Netherlands}

For a test of possible differences in radiocarbon content of different synchronous organic materials of known age, two sets of samples were dated from Roman Castellum of Valkenburg $\left(52^{\circ} 10^{\prime} \mathrm{N}\right.$ Lat, $4^{\circ} 26^{\prime} \mathrm{E}$ Long), province of South Holland, excavated by A. E. van Giffen (van Giffen, 1948) and Glasbergen.

GrN-4520. Valkenburg, coffin $1770 \pm 35$

Wood from coffin, containing human corpse. Subm. by J. D. van der Waals. $\delta \mathrm{C}^{13}=-27.0 \%$.

GrN-4525. Valkenburg, bone

$2120 \pm 40$

170 в.C.

Bone from human corpse in coffin. Subm. by J. D. van der Waals. $\delta \mathrm{C}^{13}=-18.1 \%$.

GrN-4741. Valkenburg 7451.

$2015 \pm 40$

Charcoal from post belonging to 3rd castellum, burnt in A.D. 69 . Subm. by W. Glasbergen. $\delta \mathrm{C}^{13}=-27.1 \%$.

GrN-4743. Valkenburg $\mathbf{7 4 5 3}$

$$
1990 \pm 50
$$

40 в.c.

Uncharred wood from same post. Subm. by W. Glasbergen. $\delta \mathrm{C}^{13}=$ $-27.4 \%$.

General Comment: bone date is apparently too high. A summary article on bone dating is planned by one of us (J.C.V.). Charcoal and wood date agree with each other, but are ca. a century too high compared with historical date. This difference is of little importance in view of uncertainty in time that elapsed since tree was actually cut and fluctuations of original $\mathrm{C}^{14}$ content, resulting in anomalies between radiocarbon and historical age.

\section{GrN-4672. Rijnsburg, Netherlands}

$$
1480 \pm 30
$$

Wood from sheet pile along creek found during excavation of Early Medieval settlement at Rijnsburg (52 $12^{\prime} \mathrm{N}$ Lat, $4^{\circ} 26^{\prime} \mathrm{E}$ Long), 
province of South Holland, by W. A. van Es and H. H. van Regteren Altena. Settlement occurs below foundations of Medieval abbey. Sample would date first phase of settlement. Expected age 7-9th century A.D. Subm. by W. A. van Es, Rijksdienst voor het Oudheidkundig Bodemonderzoek, Amersfoort. Comment: date is earlier than expected. $\delta \mathrm{C}^{13}=$ $-29.2 \%$.

\section{Groningen series, Netherlands}

During excavation 1965 in church St. Martinus at Groningen $\left(53^{\circ}\right.$ 13' N Lat, $6^{\circ} 34^{\prime} \mathrm{E}$ Long) by $\mathrm{H}$. Halbertsma, Rijksdienst voor het Oudheidkundig Bodemonderzoek, Amersfoort, a grave was found beneath oldest floor of church, expected to date from ca. A.D. 800. From this grave both coffin and skeleton were dated. For comparison a new measurement was made of old check sample of wood from below St. Walburg church, immediately adjacent to St. Martinus church (Groningen I).

GrN-4464. Groningen, St. Martinus church, coffin

$$
1290 \pm \mathbf{5 0}
$$

A.D. 660

Wood from coffin (outer part of trunk). $\delta \mathrm{C}^{13}=-24.7 \%$.

GrN-4456. Groningen, St. Martinus church, bone

$1270 \pm 50$

Bone from skeleton in same coffin. $\delta \mathrm{C}^{13}=-19.0 \%$.

\section{GrN-4268. Groningen, St. Walburg} church

$1300 \pm 40$

Wood from post below St. Walburg church. $\delta \mathrm{C}^{13}=-26.6 \%$.

General Comment: in this case, no difference was found between bone and wood. St. Walburg sample appears to be of same age as burial. Together these dates suggest important habitation phase. Preservation of wood in both cases is, in local geologic situation, argument for contemporaneity. Some common causes must have favoured the preservation; this may have been intensive habitation with accumulation of organic debris. St. Walburg wood itself has been used frequently as inter-laboratory check sample. Values comparable to present one have been obtained at Copenhagen (K-143: $1380 \pm$ 120; Copenhagen III), Lamont (L-292: $1250 \pm 150$; Lamont V), Victoria (V-28: $1170 \pm 70$; Victoria I) and Heidelberg (H-8-7: $1245 \pm 130$; Heidelberg I). Apart from early Chicago dates, which were much too old, early Groningen measurements as well as measurements from other labs. (for list, see Uppsala I, p. 100) gave values between 800 and 1100 yr B.P.

\section{GrN-4713. Dokkum, Netherlands}

$960 \pm 50$

\section{A.D. 990}

Outer year rings of wooden post, forming part of wooden church, preceding stone 11 th century St. Boniface church, on artificial mound at 
Dokkum (53 20 $\mathrm{N}$ Lat, $6^{\circ} 0^{\prime} \mathrm{E}$ Long), province of Friesland (Halbertsma, 1964). Excavation 1965 by H. Halbertsma, who subm. sample. Coll. by W. A. Casparie. Expected age: between approx. A.D. 760 (date of building mound) and A.D. 1050. Comment: wooden building apparently does not belong to earliest constructions which could be expected on church mound. $\delta \mathrm{C}^{13}=-27.3 \%$.

GrN-4836. Schinveld, Netherlands

A.D. 1150

$800 \pm 65$

Charcoal found in pot in post-hole of shed above firing place of pottery kiln Beekstraat 19, at Schinveld $\left(50^{\circ} 58^{\prime} \mathrm{N}\right.$ Lat, $5^{\circ} 59^{\prime} \mathrm{E}$ Long), province of Limburg. Excavated 1960 by A. Bruijn (Bruijn, 1961). Date of approx. A.D. 1125 was expected on basis of occurrence of pottery in castles with known destruction date. Depth approx. $1.00 \mathrm{~m}$. Subm. by J. A. Brongers, Rijksdienst voor het Oudheidkundig Bodemonderzoek, Amersfoort. Comment: date according to expectation.

$880 \pm 45$

\section{GrN-4835. Nieuwenhagen, Netherlands}

A.D. 1070

Charcoal fragments from firing layers of pottery kiln Valckshof at Nieuwenhagen $\left(50^{\circ} 54^{\prime} \mathrm{N}\right.$ Lat, $6^{\circ} 02^{\prime} \mathrm{E}$ Long), province of Limburg, excavated 1965 by A. Bruijn. Kiln has been in use for short time only. Depth $1.75 \mathrm{~m}$. Expected age first half of 12 th century A.D. Subm. by J. A. Brongers. Comment: date according to expectation. $\delta \mathrm{C}^{13}=-25.8 \% \mathrm{c}$.

\section{B. Other Countries}

\section{GrN-4704. Arad, Israel}

$4335 \pm 65$ 2385 B.C.

Charcoal from room (Locus 1240) at depth of $0.98 \mathrm{~m}$, in Early Bronze age II city of Arad $\left(31^{\circ} 15^{\prime} \mathrm{N}\right.$ Lat, $35^{\circ} 10^{\prime} \mathrm{E}$ Long), excavated by R. Amiran, the S. Bronfman Biblical and Archaeol. Mus., Israel Mus., Jerusalem, Israel. Coll. 1965 and subm. by excavator. Comment: all four strata of city correspond together to 1st Dynasty of Egypt, beginning of which is dated either at ca. 3150 B.c. or 2850 B.c., and which must have lasted more than 2 centuries. Even for short chronology radiocarbon date appears too young. Same deviation was found for samples from first Dynasty cemetery of Saqqara (GrN-1100: $4360 \pm 60$; GrN-1109: $4460 \pm 55 ;$ GrN-689: $4450 \pm$ 100; GrN-902: $4385 \pm 70)$ and for other historically dated samples from Egypt (see date lists Groningen II, p. 137 and Groningen III, p. 1556 and correction table in Groningen IV, p. 164). For other dates from Egypt, and comments see Bern IV, Rome III and UCIAA IV.

\section{Argissa series, Greece}

Apart from Early Neolithic sample GrN-4145 (see above), four samples were measured from Bronze age layers exposed during excavation of Argissa Magula, near Larissa $\left(89^{\circ} 38^{\prime} \mathrm{N}\right.$ Lat, $22^{\circ} 28^{\prime} \mathrm{E}$ Long), Thessaly, Greece (Milojčić, 1959), excavated by V. Milojčić. 
GrN-4144. Argissa 05

$4060 \pm 80$

2110 B.C.

Charcoal from burnt post of house, depth 5.90 to $6.00 \mathrm{~m}$ (planum XXC), belonging to Early Thessalian III (= Early Helladic). Expected age: before approx. 2000 в.с. $\delta \mathrm{C}^{13}=-25.1 \%$.

\section{GrN-4471. Argissa 04a}

$3960 \pm 60$

Charcoal from same level as sample $05 . \delta \mathrm{C}^{13}=-24.3 \%$.

\section{GrN-4143. Argissa 04}

$4000 \pm 70$

Charred grain from burnt storage room of house, depth 3.60 . $4.00 \mathrm{~m}$ (planum XIII b), belonging to Middle Thessalian (= Middle Helladic). Expected age: approx. 2000-1600 в.C. $\delta \mathrm{C}^{13}=-24.7 \%$.

GrN-4470. Argissa 03

$3740 \pm 35$

1790 B.C.

Charred grain from storage vessel in same level as sample $04 . \delta \mathrm{C}^{13}$ $=-23.0 \%$.

General Comment: dates are according to expectation.

\section{Deir 'Alla series, Jordan}

The Late Bronze age and Iron age tell of Deir 'Alla $\left(32^{\circ} 15^{\prime} \mathrm{N}\right.$ Lat, $35^{\circ} 30^{\prime} \mathrm{E}$ Long) in Jordan valley, Jordan, was excavated by $\mathrm{H}$. J. Franken, Univ. of Leiden, Netherlands (Franken, 1964). Samples were taken to study rate of accumulation of series of Iron age layers, which showed a characteristic cyclic, perhaps seasonal, pattern. Coll. 1964 by H. T. Waterbolk; subm. by H. T. Waterbolk and excavator.

\section{GrN-4553. Dier 'Alla D 816}

$3130 \pm 60$

Charred wood from beam of burnt Late Bronze age temple roof. Expected age approx. 1200 в.c. on basis of Egyptian import (cartouche of Taousert).

GrN-4748. Dier 'Alla D 166

$3290 \pm 50$

1340 B.C.

Ash with chaff and charred grain from one of first "seasonal" layers. Nomadic occupation immediately following temple destruction.

Gr N-4749. Dier 'Alla D 276

$3140 \pm 35$

1190 B.C.

Charred beans and grain from one of uppermost "seasonal" layers. End of nomadic occupation.

\section{GrN-4554. Deir 'Alla D 231a}

$3000 \pm 40$

Charcoal from ash layer ("street layer") on top of complex of seasonal layers. Expected age approx. 1000 B.c. Middle phase of village occupation. 
Gencral Comment: dates are in general agreement with archaeological dating; they point to fast accumulation rate. Further dates are, however, needed for more exact determination of rate. From top layers of Tell es-Sáidiyeh, within sight of Deir 'Alla, a large series of samples have yielded dates between 2410 and 2730 B.P. (Pennsylvania VIII).

\section{Timna series, Israel}

Ancient copper industries in Timna valley, W Arabah, ca. $30 \mathrm{~km}$ $\mathrm{N}$ of Elath $\left(29^{\circ} 52^{\prime} \mathrm{N}\right.$ Lat, $34^{\circ} 56^{\prime}$ E Long) on Red Sea. Excavation 1964 by B. Rothenberg, Arabah Expedition, P.O.B. 372, Tel Aviv (Rothenberg, 1962, 1965). Coll. and subm. by excavator.

GrN-4381. Timna II site $\mathbf{E}$

$1350 \pm 50$

Charcoal in small pit (C) next to copper melting furnace. Depth approx. $0.20 \mathrm{~m}$.

\section{GrN-4493. Timna II site F}

$3000 \pm 40$

Charcoal from hearth in melting-casting installation together with crucibles, slag and copper implements. Depth $0.40 \mathrm{~m}$.

General Comment: third sample (from Chalcolithic site N 39) did not contain sufficient carbonaceous material. Main period of activity in Timna Valley is in Early Iron age (12th-11th century B.C.). GrN-4493 is in agreement with archaeological expectations; GrN-4381 must be due to intrusion in Medieval times. GrN-938: $2895 \pm 65$ (Groningen III) is another sample from this mining center; it agrees with GrN-4493.

\section{Ipweger Moor series, Germany}

Four more samples were dated from series of wooden trackways in raised bog Ipweger Moor near Oldenburg (53० $10^{\prime} \mathrm{N}$ Lat, $8^{\circ} 9^{\prime} \mathrm{E}$ Long), Lower Saxony (Hayen, 1957). Earlier dates have been published in Groningen IV, p. 187-8. See also Hayen (1963). Coll. and subm. by H. Hayen, Osterkampsweg 163, Oldenburg, Germany.

\section{GrN-4394. Ipwegermoor XXXVI}

$\mathbf{3 0 5 0} \pm \mathbf{5 5}$

Wooden pin from trackway (Bohlenweg) between Büppel and

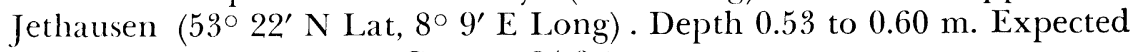
age lst-2nd century B.C. $\delta \mathrm{C}^{13}=-24.3 \%$.

GrN-4390. Ipwegermoor XII

$$
\mathbf{2 4 0 0} \pm \mathbf{5 5}
$$

450 в.C.

Wood from trackway (Bohlenweg) (53 $13^{\prime} \mathrm{N}$ Lat, $8^{\circ} 19^{\prime} \mathrm{E}$ Long) $\mathrm{SE}$ of Rastede. Depth 1.25 to $1.34 \mathrm{~m}$. Expected age 1st-2nd century B.C. $\delta C^{1 \%}=-28.5 \%$.

\section{GrN-4392. Ipwegermoor XLIII}

$2270 \pm 50$

Wood from trackway (Pfahlweg) $\quad\left(53^{\circ} 9^{\prime} \mathrm{N}\right.$ Lat, $8^{\circ} 21^{\prime} \mathrm{E}$ Long) 
in Holler Moor, E of Oldenburg. Depth approx. $0.70 \mathrm{~m}$. Expected age lst-2nd century B.C. $\delta \mathrm{C}^{13}=-26.9 \% / \mathrm{c}$.

GrN-4395. Ipwegermoor XLII

Wood from trackway (53 $8^{\prime} \mathrm{N}$ Lat, $8^{\circ} 24^{\prime} \mathrm{E}$ Long) in Wittemoor near Hude, $\mathrm{N}$ of Reiherholz. Depth 1.03 to $1.05 \mathrm{~m}$. Expected age approx. B.C. $/$ A.D. $\delta \mathrm{C}^{13}=-26.0 \%$ c.

General Comment: dates are in general somewhat older than expected.

\section{GrN-4705. Knetzgau, Germany}

$2930 \pm 40$

Charcoal from burnt wooden post, forming part of defensive earthwork of hillfort Grosser Knetzberg, Forst Neuhaus, near Knetzgau (49 $55^{\prime} \mathrm{N}$ Lat, $10^{\circ} 25^{\prime} \mathrm{E}$ Long), Landkreis Hassfurt, Bavaria, excavated by J. Wabra, Bad Kissingen, Bavaria, Germany. Urnfield period pottery sherds occur below bank. Comment: date proves that fortification dates back to Urnfield times. $\delta \mathrm{C}^{13}=-25.3 \%$.

\section{Schwanberg series, Germany}

Burnt wooden posts forming part of defensive earth work at Schwan-

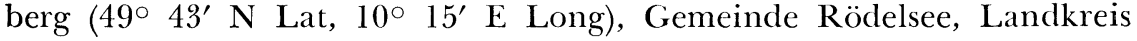
Kitzingen. Excavated 1959 by C. Pescheck, Bayerisches Landesamt für Denkmalpflege, Zweigstelle Franken, Würzburg, Bavaria, Germany. Expected age 100 B.C.-A.D. 200. Subm. by excavator.

GrN-4466. Schwanberg A

$2860 \pm 50$

910 B.C.

GrN-4467. Schwanberg B

$2860 \pm \mathbf{5 0}$

910 B.C.

General Comment: dates are much older than expected. $\delta \mathrm{C}^{13}=-23.2^{\prime} / \mathrm{o}$ (sample A) and $-23.6 \%$ (sample B).

\section{GrN-2087. Brno-Obřany, Czechoslovakia}

Charred wood from bank of hillfort "Hradisko" at Brno-Obřany (49 $12^{\prime} \mathrm{N}$ Lat, $16^{\circ} 34^{\prime} \mathrm{E}$ Long), Moravia, excavated 1958 by F. Adámek. On archaeological grounds date of approx. 500 B.c. (Hallstatt period) was expected. Vertical depth 2.00 to $2.20 \mathrm{~m}$, horizontal depth $0.75 \mathrm{~m}$. Subm. by K. Valoch, Moravské Mus., Brno. Comment: date suggests that hillfort dates back to Late Bronze age Lusetian culture.

\section{GrN-4391. Lohne-Diepholz, Germany}

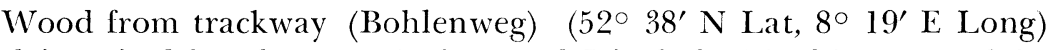
found in raised bog between Lohne and Diepholz, $\mathrm{N}$ of Dümmer lake, Kreis Diepholz (in part), Lower Saxony. Trackway is numbered III $(\mathrm{Pr})$ in Hayen's system (Hayen, 1957). Depth 1.04 to $1.12 \mathrm{~m}$. Expected 
age Middle Bronze age. Coll. and subm. by H. Hayen. Comment: date is somewhat younger than expected. $\delta \mathrm{G}^{13}=-25.3 \%$.

\section{Langenmoor series, Germany}

Two samples from prehistoric trackways in Langenmoor (complex Ls), Kreis Land Hadeln, near Oldenburg. Lower Saxony (Hayen, 1957). Subm. by H. Hayen.

GrN-4396. Trackway VI (Ls)

$\mathbf{2 4 4 0} \pm \mathbf{5 0}$

490 B.c.

Wood from trackway (Bohlendamm) (53 $34^{\prime} \mathrm{N}$ Lat, $9^{\circ} 7^{\prime}$ E Long) between Langel and Abbenseth, S of Lamstedt. Depth $1.80 \mathrm{~m}$. Expected age: Bronze age. Coll. by W. Klenck. $\delta \mathrm{C}^{13}=-24.9 \%$.

$$
2010 \pm 55
$$

GrN-4393. Trackway II (Ls)

60 B.c.

Wood from trackway (Bohlenweg) (53 $34^{\prime} \mathrm{N}$ Lat, $8^{\circ} 59^{\prime} \mathrm{E}$ Long), in Langenmoor near Grossenhain. Depth 0.35 to $0.80 \mathrm{~m}$. Expected age: pre-Roman Iron Age. Coll. by H. Hayen. $\delta \mathrm{C}^{13}=-27.8 \%$.

General Comment: dates are somewhat younger than expected.

\section{Hatzum series, Germany}

Wood from prehistoric settlement of Hatzum $\left(55^{\circ} 18^{\prime} \mathrm{N}\right.$ Lat, $7^{\circ} 20^{\prime}$ E Long), Kreis Leer, Lower Saxony, excavated 1963 by W. Haarnagel, Niedersächsische Landesstelle für Marschen- und Wurtenforschung, Wilhelmshaven, Germany (Haarnagel, 1965).

\section{GrN-4344. Hatzum}

$$
2460 \pm 50
$$

Wood from earliest habitation level. Subm. by A. E. van Giffen. $\delta \mathrm{C}^{13}=-27.6 \%$.

\section{GrN-4669. Hatzum H 180}

$$
2445 \pm 35
$$

495 B.C.

Wood from wall post of house. Floor level $-0.75 \mathrm{~m}$ O.D. $(1.80 \mathrm{~m}$ below surface). Estimated age 7 th century B.c. Subm. by W. Haarnagel. $\delta \mathrm{C}^{13}=-30.6 \%$.

\section{GrN-4668. Hatzum H 114}

Wood from inner post of house. Floor level -0.40 O.D. (approx. $1.45 \mathrm{~m}$ below surface). Estimated age 500 в.c. Subm. by W. Haarnagel. $\delta \mathrm{C}^{13}=-30.3 \%$.

General Comment: dates, although somewhat younger than expected, are in agreement with archeological dating of site (Hallstatt $\mathrm{D} / \mathrm{La}$ Tène A). For a contemporaneous settlement in neighborhood (Jemgum) an early Groningen measurement is available (GrN-129: $2335 \pm 70$; Groningen I) . 


\section{GrN-4708. Steenberg, Belgium}

Charcoal from burnt beam in Gallo-Roman culture layer at Steenberg near Grobbendonk (51 $10^{\prime} \mathrm{N}$ Lat, $4{ }^{\circ} 45^{\prime} \mathrm{E}$ Long), province of Antwerp. Depth $1.20 \mathrm{~m}$. Excavated 1965 by E. Verhofstadt, 73 Constitutiestraat, Antwerp, who coll. and subm. sample. Comment: date agrees with archaeological expectation. $\delta \mathrm{C}^{13}=-25.0 \%$.

\section{GrN-4615. Chodlick, Poland}

$$
1160 \pm 50
$$

Charcoal from heavy wooden construction in middle bank of three concentric banks of Slavonic "Burgwall" of Chodlik near Lublin $\left(51^{\circ}\right.$ 12' N Lat, 220 38' E Long), Pow. Opole-Lubelskie, excavated by A. Gardawski. Depth $0.40 \mathrm{~m}$. Expected age 7 th-8th century A.D. Coll. 1964 and subm. by A. Gardawski, Lublin and J. A. Bakker, Amsterdam. Comment: date agrees with expectation. $\delta \mathrm{C}^{13}=-26.8 \%$.

\section{GrN-4654. Hallstatt, Austria}

$$
330 \pm 50
$$

\section{A.D. 1620}

Wood from old mine gallery leading to deserted warm bath installation at Hallstatt $\left(47^{\circ} 35^{\prime} \mathrm{N}\right.$ Lat, $13^{\circ} 38^{\prime} \mathrm{E}$ Long) (Morton, 1932). Expected age 200-400 yr. Coll. and subm. by F. Morton, Hallstatt, Austria. Comment: date agrees with expectation. $\delta \mathrm{C}^{13}=-24.8 \%$.

\section{Southern Africa}

\section{GrN-4407. Amanzi, South Africa, extract}

\section{GrN-4546. Amanzi (enriched)}

$60,600 \pm 1100$

In spring sediments on Amanzi Estates $\left(33^{\circ} 42^{\prime} \mathrm{S}\right.$ Lat, $25^{\circ} 29^{\prime} \mathrm{E}$ Long) NE of Uitenhage, Cape Province, abundant Early Stone age (Acheulian) artifacts have been excavated by R. R. Inskeep. A number of logs were found associated with artifacts. One of these was dated. Coll. 1963 and subm. 1964 by R. R. Inskeep, School of African Studies, Univ. of Cape Town. Comment: some $250 \mathrm{~g}$ of wood gave $148 \mathrm{~L} \mathrm{CO}_{2}$ after pretreatment and combustion. This was enriched 12.43 times before measurement. Date of $60,600 \pm 1100$ considered minimum for occupation (cf. de Vries et al., in preparation).

\section{Kalambo Falls series, Zambia}

From 1963 excavations at Sites $A$ and $C$ at Kalambo Falls $\left(08^{\circ} 35^{\prime}\right.$ $S$ Lat, $31^{\circ} 15^{\prime}$ E Long) a further series dated (cf. Groningen V). Coll. by M. R. Kleindienst, C. M. Keller, and J. D. Clark (Site A) and F. van Noten and J. D. Clark (Site C). Summary of stratigraphy in Clark and van Zinderen Bakker (1964). Subm. 1964 by J. D. Clark, Dept. of Anthropol., Univ. of California, Berkeley. 
GrN-4896. Kalambo Falls A4.19 (enriched)

Wooden $\log$ from "Transitional Acheulian" layer on river face between Trenches Al and A4 correlated with Surface IV in Al excavation. Comment: as sample proved beyond normal range ca. $250 \mathrm{~g}$ were pretreated and combusted to give $185 \mathrm{~L}$ of $\mathrm{CO}_{2}$ in which $\mathrm{C}^{14}$ was enriched 12.81 times before measurement. Sample represents younger culture than Kalambo Falls /57. Date for latter sample in Groningen V needs correction; corrected date is GrN-2644: 60,300 \pm 750 . Both figures are to be considered only minimum. GrN-4896 suggests that transition from Acheulian to Sangoan took place at least 60,000 yr ago, but Transitional Acheulian may have lasted very long time.

GrN-4260. Kalambo Falls A4.11, charcoal

\section{GrN-4259. Kalambo Falls A4.12, wood}

GrN-4227. Kalambo Falls A4.10, wood
38.850

$37,450=600$ $\mathbf{3 5 , 5 0 0}$ в.C.

recent

Charcoal and wood from Sangoan layers in Squares K11, K12 of River Face excavation. Comment: sample A4.10 contained (101 \pm 0.5$) \%$ of modern standard and is obviously recent, $\delta \mathrm{C}^{13}=-25.7 \%$. Sample A4.1 l was too small to make more accurate determination. In comparison with other Sangoan dates from same site, which average about 41,000 B.P., GrN-4259 seems somewhat young, but as it was possibly a root, it may date from higher level.

GrN-4261. Kalambo Falls A4.5, extract

Small charcoal sample from sterile black clay in Trench A4, Pit 1. Comments: predates Middle Stone age, compare GrN-3196 and 3226 in Groningen V.

GrN-4648. Kalambo Falls A4.7

$31,660 \pm 600$ 29,710 в.c.

Cilay with specks of charcoal in Trench A4, Pit 2, overlying Stone Line II with first Middle Stone age artifacts. Comment: date acceptable for M.S. age.

\section{GrN-4224. Kalambo Falls CS.11}

GrN-4225. Kalambo Falls CS.13

$$
\begin{aligned}
& 3920 \pm 40 \\
& 1970 \text { в.C. } \\
& 3850 \pm 40 \\
& 1900 \text { в.C. } \\
& 2730 \pm 40 \\
& 780 \text { в.C. }
\end{aligned}
$$$$
\text { GrN-4223. Kalambo Falls CS.10 }
$$

Three charcoal samples from (Microlithic) Late Stone age occupation floor at Site Ci on top of $9 \mathrm{~m}$ terrace at ca. $1.1 \mathrm{~m}$ depth (C.S. 11 and 
CS. 13) and ca. $1.0 \mathrm{~m}$ depth (CS. 10). Comment: these are first dates for L.S. age in basin. GrN-4224 and GrN-4225 date earlier part of occupation and $\mathrm{GrN}-4223$ the end. $\delta \mathrm{C}^{13}(\mathrm{GrN}-4223)=-24.2 \%$.

\section{GrN-4646. Kalambo Falls CS.6}

\section{GrN-4647. Kalambo Falls CS.9}

$1605 \pm 40$

\section{A.D. 345}

$1520 \pm 40$

Two charcoal samples from "grave shafts" 8 and 11 at Site C associated with channelled ware pottery of Kalambo culture (Iron age). Comment: considerably older than other dates for Kalambo culture from Site B 2: GrN-3189: $370 \pm 50$ B.P. and GrN-3580: $930 \pm 40$ в.P. (Groninegn V), but in keeping with L.S. age dates, above.

\section{GrN-4226. Kalambo Falls A4.1}

$2470 \pm 40$

Large hard charcoal sample from red surface soil at $34 \mathrm{~cm}$ depth in Pit 1, Trench A.4 suspected to post-date Kalambo culture because it overlies levels with channelled ware pottery. Comment: obviously much too old. Suspicion is that sample was redeposited from older levels higher up slope. $\delta \mathrm{C}^{13}=-23.5 \%$.

\section{Montagu series, South Africa}

Cave ca. $8 \mathrm{~km} \mathrm{E}$ of Montagu (33 $50^{\prime} \mathrm{S}$ Lat, $20^{\circ} 10^{\prime} \mathrm{E}$ Long), Cape Province, has revealed stratified sequence of Early, Middle, and Late Stone age culture layers. Site re-excavated 1964 by C. Keller who coll. samples which were subm. 1965 by J. D. Clark.

\section{GrN-4728. Montagu MSA 46}

$45,900 \pm 2100$ 43,950 в.C.

Charcoal lumps from $3.1 \mathrm{~m}$ below datum in Sq. F25 in first layer with Late M.S. age (2nd Intermediate) assemblage comparable to M.S. age at Pears' Cave, Fishhoek, and Mosselbay but which also shows Magosian characteristics (J.D.C.). Layer below contains evolved Acheulian. Comment: unexpectedly early for Late M.S. age. $\delta \mathrm{C}^{13}=-25.9 \%$.

\section{GrN-4726. Montagu MSA 21}

$23,200 \pm 180$

Scattered charcoal fragments from uppermost Late M.S. age layer which slopes sharply from 1.55 to $2.24 \mathrm{~m}$ below datum; Sq. F 30 . Comment: also older than expected. $\delta \mathrm{C}^{13}=-25.7 \%$.

GrN-4725. Montagu LSA 8A

$7100 \pm 45$

5150 B.C.

Charcoal from hearth in Sq. $25 \mathrm{E} \& \mathrm{~F}$ at $1.88 \mathrm{~m}$ below datum representing end of L.S. age (Wilton ?) occupation. Comment: $\delta \mathrm{C}^{13}=$ $-25.0 \%$. 


\section{Gordon's Bay series, South Africa}

In dune on beach at Gordon's Bay $\left(34^{\circ} 9^{\prime} 20^{\prime \prime} \mathrm{S} \mathrm{Lat,} 18^{\circ} 51^{\prime} 55^{\prime \prime} \mathrm{E}\right.$ Long), $4 \mathrm{~km}$ from Somerset Strand, Cape Province, stratified occupation site of "Strandlopers" (shell midden) was excavated by F. van Noten in 1964. In 17th century Europeans encountered Strandloper folk with a Later Stone age economy based on seafood. In dune at Gordons Bay three culture layers separated by sterile sand were uncovered (van Noten, 1965). Coll. 1964 and subm. by F. van Noten, Tervuren and R. Inskeep, Univ. of Cape Town.

\section{GrN-4374. Gordon's Bay 3}

Charcoal from base of lower occupation layer at $3.2 \mathrm{~m}$ depth. Comment: $\delta \mathrm{C}^{13}=-23.2 \%$.

\section{GrN-4373. Gordon's Bay 2}

$2980 \pm 60$

Charcoal from middle occupation layer at $2 \mathrm{~m}$ depth. Comment: $\delta \mathrm{C}^{13}=-23.0 \%$.

\section{GrN-4372. Gordon's Bay 1}

$2700 \pm 40$

Charcoal from upper occupation layer at 0.45 to $1.10 \mathrm{~m}$ depth. Comment: $\delta \mathrm{C}^{13}=-23.5 \%$.

General Comment: associated finds consist of large amount of shell and fish-bone, and bones of rodents, tortoise and seldomly antelope. Lithic assemblage is a typical Smithfield (?) with large "pebble choppers," thick scrapers, and irregular flakes. Skeletal material has been recovered from other parts of dune. These are first dates for a Strandloper shell midden and indicate high antiquity and long cluration.

\section{Gwisho Springs series, Zambia}

Around Gwisho Hotsprings on Lochinvar Ranch $\left(16^{\circ} 0^{\prime} \mathrm{S}\right.$ Lat, $27^{\circ}$ $10^{\prime} \mathrm{E}$ Long) $45 \mathrm{~km} \mathrm{NW}$ of Monze, S. Zambia, four Wilton sites are known. Site B, excavated in 1964, yielded 10 human burials and wooden and stone artifacts. Coll. and subm. 1964 by F. van Noten, Koninklijk Museum voor Midden-Afrika, Tervuren, Belgium.

\section{GrN-4305. Gwisho Springs B1}

$3680 \pm 70$

1730 в.C.

Wood from floor of windbreak (hut $\vdots$ ) at $0.46 \mathrm{~m}$ depth in Trench II, Sq. C, Level 6 of Site B. Comment: $\delta \mathrm{C}^{13}=-23.4 \%$.

GrN-4306. Gwisho Springs B2

$\mathbf{3 6 8 0} \pm \mathbf{7 0}$

1730 B.C.

Scattered charcoal from living floor at $0.62 \mathrm{~cm}$ depth in Trench VI, Sq. A, Level 8 of Site $\mathbf{B}$ representing middle phase of occupation. Comment: $\delta \mathrm{C}^{13}=-24.6 \%$. 


\section{GrN-4307. Gwisho Springs B3}

Twigs and grass from 1.7 to $1.8 \mathrm{~m}$ depth in Trench $1 \mathrm{~V}$, representing earliest phase of occupation. Comment: $\delta \mathrm{C}^{13}=-24.6 \%$. General Comment: expected age for Wilton culture was 4500-5000 в.P.; dates indicate longer duration and contemporaneity with Later Stone age culture at Kalambo Falls (see above). Compare UCLA-174: $4700 \pm$ 100 and UCLA-173: 4300 \pm 100 for another of the sites at Gwisho Hotsprings (UCLA II).

\section{Palabora series, South Africa}

Palabora (24 $04^{\prime} \mathrm{S}$ Lat, $31^{\circ} 06^{\prime} \mathrm{E}$ Long) ca. $100 \mathrm{~km} \mathrm{E}$ of Zaneen, NE Transvaal, is one of larger centers of metal production in prehistoric South Africa. Extensive tunneling for copper ore took place on Loolekop and many smelting furnaces are found in vicinity.

\section{GrN-4215. Loolekop}

$160 \pm 30$

Stick found in underground passage of prehistoric mine. Subm. 1964 by A. P. du Toit, Pretoria. Comment: from known variation of $\mathrm{C}^{1+}$ content in past, estimated historic date is between A.D. 1660 and A.D. 1800 $\delta \mathrm{C}^{13}=-24.5 \%$.

\section{GrN-4928. Nareng furnace}

$110 \pm 25$

From layer of charcoal around furnace covered by $40 \mathrm{~cm}$ of slag, ca. $1.5 \mathrm{~km}$ E of Palabora. Coll. and subm. 1966 by R. J. Mason, Univ. of Witwatersrand, Johannesburg. Comment: estimated historic date is A.D. 1840 or A.D. $1700 . \delta C^{13}=-25.4 \%$.

\section{GrN-4929. Shangaankop furnace}

$$
-110 \pm 40
$$

Scattered charcoal in furnace enclosure N.15 at Shangaankop ca. $3 \mathrm{~km} \mathrm{NE}$ of Palabora, ca. 6 to $12 \mathrm{~cm}$ below surface. Coll. and subm. 1966 by R. J. Mason. Comment: obviously recent; dates from A.D. $1956 \pm 1$. $\delta \mathrm{C}^{13}=-24.4 \%$.

General Comment: there is no recollection of metal working among local inhabitants and operations must have been abandoned well before 1900 .

\section{Klipriviersberg series, South Africa}

On farm Klipriviersberg ca. $7 \mathrm{~km} \mathrm{~S}$ of Johannesburg $\left(26^{\circ} 11^{\prime} \mathrm{S}\right.$ Lat, $28^{\circ}$ (02' E Long), Transvaal, an Iron age settlement with stone hut walls is being excavated by R. J. Mason. Two occupation levels can be distinguished. In Transvaal Mason has located ca. 1000 such settlements by aerial photography. This Iron age Culture was destroyed in 1882 by Moselikatse. For review see Mason (1965). Subm. 1965 by R. J. Mason. 


\section{GrN-4796. Klipriviersberg 1}

$105=50$

Charcoal from ca. $60 \mathrm{~cm}$ depth within walling; position $\mathrm{Db} / \mathrm{Ea} / 11$. Comment: from known variation of $\mathrm{C}^{14}$ content in past estimated historic date is A.D. 1845 or A.D. $1700 ; \delta \mathrm{C}^{13}=-27.8 \%$.

\section{GrN-4926. Klipriviersberg 2}

$$
195 \pm 45
$$

Scattered charcoal among fragments of collapsed wall of Hut 210/ $\mathrm{E}(\mathrm{i})$ from upper habitation layer, depth ca. $10 \mathrm{~cm}$. Comment: estimated historic date is A.D. 1755 or A.D. $1650 ; \delta \mathrm{C}^{13}=-24.5 \%$.

\section{GrN-4927. Klipriviersberg 3}

Scattered charcoal in ash layer on floor of Hut 220/60 representing lower habitation layer, depth 10 to $15 \mathrm{~cm}$. Comment: estimated historic date is A.D. 1770 or A.D. $1650 . \delta \mathrm{C}^{13}=-23.8 \%$ c.

General Comment: fluctuations in $\mathrm{C}^{14}$ content since A.D. 1500 make it difficult to place these Iron age sites in stratigraphic order.

\section{GrN-4797. Waterval RV15, South Africa}

$230 \pm 40$

Charcoal from Iron age site at Waterval in Johannesburg $\left(26^{\circ} 11^{\prime}\right.$ $S$ Lat, $28^{\circ} 02^{\prime}$ E Long), Transvaal. Comment: estimated historical date is A.D. 1640 which is similar to dates for nearby Klipriviersberg, above. $\delta \mathrm{C}^{13}=-23.9 \%$.

\section{Paredão series, Brasil}

$$
\text { v. NEW WORLD }
$$

Charcoal from archeological site Paredão $\left(3^{\circ} 15^{\prime} \mathrm{S}\right.$ Lat, $60^{\circ} \mathrm{W}$ Long), approx. $10 \mathrm{~km} \mathrm{~S}$ of Manaus, Amazonas. Subm. by H. Sioli, Hydrobiologische Anstalt der Max-Planck-Gesellschaft, Plön (Holstein), W. Germany.

\section{GrN-4328. Paredão 1}

$$
2400 \pm 75
$$

Charcoal from Cut I, depth 0.45 to $0.60 \mathrm{~m}$, corresponding to beginning of Guarita phase. Expected age approx. A.D. 1000. Coll. 1961 by P. P. Hilbert. $\delta \mathrm{C}^{13}=-26.2 \%$.

\section{GrN-4330. Paredão 3}

$$
1070 \pm 70
$$

Charcoal from Cut II, depth 0.75 to $0.90 \mathrm{~m}$, corresponding to beginning of Paredão-phase. Expected age: earlier than A.D. 500. Coll. 1961 by E. J. Fittkau. $\delta \mathrm{C}^{13}=-26.1 \%$.

\section{GrN-4329. Paredão 2}

$$
1080 \pm 70
$$

Charcoal from Cut II, depth 0.45 to $0.60 \mathrm{~m}$, corresponding to well- 
developed Parcdão phase, preceeding Guarita phase. Expected age A.D. 500-1000. Coll. 1961 by E. J. Fittkau. $\delta \mathrm{C}^{13}=-26.1 \%$.

General Comment: GrN-4328 is much older than expected.

\section{GrN-4412. Careiro, Brasil}

$1150 \pm 75$

Charcoal from archaeological site Careiro $\left(3^{\circ} 20^{\prime} \mathrm{S}\right.$ Lat, $59^{\circ} 45^{\prime} \mathrm{W}$ Long), approx. $40 \mathrm{~km} \mathrm{SE}$ of Manaus, Amazonas. Coll. 1961 by P. P. Hilbert. Depth 1.35 to $1.50 \mathrm{~m}$. Associated with pottery of Paredão complex (cf. samples Paredão 2 and 3). Expected age approx. A.D. 500 and earlier. Subm.by H. Sioli.

\section{Caiambé series, Brasil}

Charcoal from archaeological site Caiambé $\left(3^{\circ} 30^{\prime} \mathrm{S}\right.$ Lat, $64^{\circ} 30^{\prime}$ W Long), on right bank of Rio Solimoes, approx. $40 \mathrm{~km} \mathrm{~S}$ of Tefé, Brasil. Depth 1.40 to $1.50 \mathrm{~m}$. Transition between culture of Guarita tradition and preceding Caiambé phase. Expected age: before A.D. 500. Coll. 1961 by E. J. Fittkau; subm. by H. Sioli.

\section{GrN-4331. Caiambé A}

GrN-4332. Caiambé B$$
\text { A.D. } 640
$$

$$
1220 \pm 60
$$

A.D. 730

General Comment: $\delta \mathrm{C}^{13}=-25.9 \%$ (Sample A) and $-25.6 \%$ (Sample B).

\section{Broken "K" ranch series, U.S.A.}

Broken " $\mathrm{K}$ " ranch site (ca. $34^{\circ} 30^{\prime} \mathrm{N}$ Lat, $109^{\circ} 30^{\prime} \mathrm{W}$ Long), Arizona, expected to be later than Carter Ranch site (GrN-4112: $830 \pm$ 70, see Groningen V; tree-ring date A.D. 1129) and somewhat earlier than Table Rock Pueblo (GrN-1997; $615 \pm 55$; tree-ring date A.D. 1331). Subm. by P. S. Martin, Chicago Nat. History Mus., Chicago.

\section{GrN-4360. Broken "K" Ranch, Room $20 \quad$ A.D. 810}

$1140 \pm 70$

Charcoal from ash-pit in Room 20. $\delta \mathrm{C}^{13}=-21.5 \%$.

GrN-4361. Broken "K" Ranch, Room 37 A.D. 960

$990 \pm 70$

Charcoal from fire-pit in Room 37. $\delta \mathrm{C}^{13}=-19.2 \%$.

$985 \pm 50$

GrN-4351. Broken "K" Ranch, Room 41

A.D. 965

Charcoal from fire-pit in Room 41, Kiwa. $\delta \mathrm{C}^{13}=-20.3 \%$.

$920 \pm 65$

GrN-4347. Broken "K" Ranch, Room 78 A.D. 1030

Charcoal from fire-pit in Room 78 , level II. $\delta \mathrm{C}^{13}=-19.5 \%$. 
GrN-4555. Broken "K" Ranch, Room 11

Wood from north-south roof beam from Room 11, dated by $\mathbf{B}$. Bannister, Lab. of Tree-Ring Research, Tucson, Arizona, at A.D. 1260 (cutting date). Tree-rings on sample run from A.D. 1208 to A.D. 1259. $\delta \mathrm{C}^{13}=-22.8 \%$.

General Comment: GrN-4555 was measured in view of earliness of dates obtained on other samples. Taking A.D. 1235 as mean value of tree-ring date, difference is not significant, and in any case smaller than error margin. Possibility that occupation of site lasted longer than expected should be considered seriously.

\section{GrN-4652. Hawaii H8-E10}

$820 \pm 65$

Charcoal from Sq. E10 in Cave Shelter H8, South Point $\left(18^{\circ} 57^{\prime} \mathrm{N}\right.$ Lat, $155^{\circ} 42^{\prime} \mathrm{W}$ Long), Kau district, Island of Hawaii, depth 25 to 27 in. Expected age: A.D. 950. Coll. 1956 and subm. by K. P. Emory, Bernice P. Bishop Mus., Honolulu, Hawaii. Comment: for further dates from Hawaii see Groningen V (p. 359-60).

\section{Atacama series, Chile}

Neolithic site in Campo de Solor, $6 \mathrm{~km}$ from San Pedro de Atacama (22。 12' S Lat, $68^{\circ} 11^{\prime} \mathrm{W}$ Long), Chile, in desert country. Site is covered by $1.70 \mathrm{~m}$ of sand. Both samples (wood) are from doorheads. Coll. 1961 and subm. by J. Spinner, Instituto di Arqueología, Universidad Católica, Valparaiso, Chile.

\section{GrN-4124. Atacama 1}

$$
\text { A.D. } 980
$$

$970 \pm 75$

GrN-4125. Atacama 2

A.D. 1180

$$
770 \pm 65
$$

General Comment: sample GrN-4124 practically all dissolved in dilute alkali; this alkali-soluble fraction was measured. As other sample gave even younger date, there is no reason to suspect date.

\section{Yotoco Ferry series, Colombia}

Yotoco Ferry site, E of town of Yotoco (4० N Lat, $77^{\circ} \mathrm{W}$ Long), opposite confluence of Cauca with Rio Yotoco, Dept. del Valle del Cauca. Coll. by M. E. Mosely; subm. by W. M. Bray, Dept. of Ancient History, Univ., Sheffield, U.K.

GrN-4694. Yotoco IIIb

Small charcoal fragments from base of Level IIIb. Depth between $5 \mathrm{ft} 4 \mathrm{in}$. and $5 \mathrm{ft} 7 \mathrm{in}$. Site yields new pottery style, thought to date from between 300 B.C. and A.D. 1200. Coll. 1965. $\delta \mathrm{C}^{13}=-25.6 \%$. 
GrN-4940. Yotoco IIIa

A.D. 1780

$170 \pm 40$

Charcoal from Level IIIa, separated from Level IIIb by erosional unconformity (deposit in gulley cut into Bed IIIb). Pottery of Yotoco type, possibly with Sonso admixture. Depth $4 \mathrm{ft} 1 \mathrm{lin}$. Expected age: between 7 and 3 centuries ago. Coll. 1964.

General Comment: dates are late within expected time ranges.

\section{GrN-4697. Moralba, Colombia}

A.D. 1550

$400 \pm 70$

Charcoal from single piece of timber lying on surface of archeological layer Cult. 2 of settlement at Hacienda Moralba, near Mediacanoa (approx. $4^{\circ} \mathrm{N}$ Lat, $77^{\circ} \mathrm{W}$ Long), province Valle. Site yields pottery of new style ("Moralba ware"), expected to date A.D., perhaps as late as 12/13th century. Coll. 1965 and subm. by W. M. Bray. Comment: related material from nearby Calima valley had been dated at 13 th century A.D., but pottery style may have continued until time of Conquest (1540-50). $\delta \mathrm{C}^{13}=-26.2 \%$.

\section{GrN-4695. Yocambo, Colombia}

$$
\mathbf{3 7 0} \pm \mathbf{7 0}
$$

Charcoal associated with pottery, from limited area of stratified site, at Hacienda Yocambo, near Mediacanoa (4 $\mathrm{N}$ Lat, $77^{\circ} \mathrm{W}$ Long), province Valle. Depth ca. $6 \mathrm{ft}$. Pottery is related to "Moralba Ware" (see above). Coll. and subm. by W. M. Bray. Comment: date proves expected contemporaneity of Moralba and Yocambo sites. $\delta \mathrm{C}^{13}=$ $-24.6 \%$.

Date lists:

$\begin{array}{ll}\text { Berlin I } & \text { Kohl and Quitta, 1964 } \\ \text { Berlin II } & \text { Kohl and Quitta, 1966 } \\ \text { Bern I } & \text { Oeschger, Schwarz and Gfeller, 19-9 } \\ \text { Bern IV } & \text { Oeschger and Riesen, 1965 } \\ \text { Cambridge V } & \text { Godwin and Willis, 1962 } \\ \text { Copenhagen III } & \text { Tauber, 1960 } \\ \text { Groningen I } & \text { de Vries and Barendsen, 1954 } \\ \text { Groningen II } & \text { de Vries, Barendsen and Waterbolk, 1958 } \\ \text { Groningen III } & \text { de Vries and Waterbolk, 1958 } \\ \text { Groningen IV } & \text { Vogel and Waterbolk, 1963 } \\ \text { Groningen V } & \text { Vogel and Waterbolk, 1964 } \\ \text { Groningen VI } & \text { Vogel and Zagwijn, 1967 } \\ \text { Heidelberg I } & \text { Münnich, 1957 } \\ \text { Lamont V } & \text { Olson and Broecker, 1959 } \\ \text { Louvain II } & \text { Deumer, Gilot and Capron, 1964 } \\ \text { Louvain IV } & \text { Gilot, Ancion and Capron, 1966 } \\ \text { Pennsylvania VII } & \text { Sturckenrath and Ralph, 1965 } \\ \text { Rome III } & \text { Alessio, Bella, Bachechi and Cortesi, 1965 } \\ \text { UCLA II } & \text { Fergusson and Libby, 1963 } \\ \text { UCLA IV } & \text { Berger, Fergusson and Libby, 1965 } \\ \text { Uppsala I } & \text { Olsson, 1959 } \\ \text { Victoria I } & \text { Bermingham, 1966 }\end{array}$

Alessio, M., Bella, F., Bachechi, F. and Cortesi, C., 1965, University of Rome carbon-14 dates III: Radiocarbon, v. 7, p. 213-222. 
Bailloud, G., 1959, L'habitat néolithique et protohistorique des Roches, commune de Videlles: Mém. Soc. Préhist. Franc., v. 5, p. 192-214.

Berger, R., Fergusson, G. J. and Libby, W. F., 1965, UCLA radiocarbon dates IV: Radiocarbon, v. 7, p. 336-371.

Bermingham, A., 1966, Victoria natural radiocarbon measurements I: Radiocarbon, v. 8 , p. $507-521$.

Bonifay, E., 1964, La Grotte du Regourdou (Montignac, Dordogne). Stratigraphie et Industrie Lithique Moustérienne: L'Anthropologie (Paris), v. 68, p. 49-64.

Bordes, F., 1955, La stratigraphie de la grotte de Combe-Grenal, commune de Domme (Dordogne): Bull. de la Soc. Préhist. de France, v. 52, p. 426-429.

Braidwood, R. J. and Howe, B., 1960, Prehistoric investigations in Iraqi Kurdistan: Chicago, Studies in Ancient Oriental Civilization, no. 31.

Bruijn, A., 1960-61, Die mittelalterliche keramische Industrie in Schinveld: Berichten Rijksdienst Oudheidk. Bodemond., v. 10-11, p. 462-507.

Bursch, F. C., 1935, Oudheidkundige onderzoekingen te Hilversum, 1934: Oudheidk. Meded. Rijksmus. Oudh. Leiden, v. 16, p. 45-61.

Butler, J., 1966, The bronze rapier from Zwaagdijk, Gemeente Wervershoof, Prov. North Holland: Ber. Rijksdienst Oudheidk. Bodemond., v. 14, p. 37-43.

Butter, J., 1930, Opmerkingen over "Tardenoisien" in Nederland: De Levende Natuur, v. 35, p. $185-191$.

1957, Vondsten in het oerstroomdal van de Overijsselse Vecht: Tijdschrift Kon. Ned. Aardr. Genootschap, v. 74, p. 239-241.

Chernysh, A. P., 1962, Anthropozoikum, v. 10, p. 49-52.

Clark, J. D. and Van Zinderen Bakker, E. M., 1964, Prehistoric culture and Pleistocene vegetation at the Kalambo Falls, Northern Rhodesia: Nature, v. 201, p. 971-975.

Clark, J. G. D., 1963, Neolithic bows from Somerset, England, and the prehistory of archery in Northwest Europe: Proc. Prehist. Soc., v. 29, p. 50-98.

de Contenson, H. and van Liere, W. J., 1964, Sondages à tell Ramad en 1963. Rapport préliminaire: Annales Archéologiques de Syrie, v. 14, p. 109-124.

__ (in press), Premiers pas vers une chronologie absolue à tell Ramad: Annales Archéologiques de Syrie.

(in press), Premier sondage à Bouqras en 1965. Rapport préliminaire: Annales Archéologiques de Syrie.

Delporte, H., 1962, Le gisement paléolithique de la Rochette: Gallia-Préhistoire, v. 5, p. $1-22$.

1963, Les Niveaux Aurignaciens de la Rochette: Bull. Soc. d'Etudes et de Recherches Préhist. et Inst. Pratique de Préhist. (Les Eyzies), v. 13, p. 1-24.

Deumer, J. M., Gilot, E. and Capron, P. C., 1964, Louvain natural radiocarbon measurements: Radiocarbon, v. 6, p. 160-166.

Drichaus, J., 1960, Die Altheimer Gruppe: Mainz.

Ehrenberg, H., 1959, Die urzeitlichen Fundstellen und Funde in der Salzofenhöhle, Steiermark: Archaeologia Austriaca, v. 25, p. 8-24.

van Es, W. A., 1967: Wijster, a native village beyond the imperial frontier 150-425 A.D.; Thesis, Groningen.

Faure, H. and Hugot, H. J., 1964, Chronologie absolue du Quaternaire en Afrique de l'Ouest: Bull. de l'IFAN, v. 28, p. 384-395.

Fergusson, G. J. and Libby, W. F., 1963, UCLA radiocarbon dates II: Radiocarbon, v. 5 , p. $1-22$

Franken, H. J., 1964, The stratigraphic context of the clay tablets found at Deir 'Alla: Palestine Explor. Quat., p. 73-78.

van Giffen, A. E., 1936, Der Warf in Ezinge und seine westgermanischen Häuser: Germania, v. 20, p. $40-47$.

1948, De Romeinsche Castella in den dorpsheuvel te Valkenburg aan den Rijn (Z.H.): Jaarversl. Verenig. v .Terpenonderzoek, v. 25-28, p. 1-181.

Gilot, E., Ancion, N. and Capron, P. C., 1966, Louvain natural radiocarbon measurements IV: Radiocarbon, v. 8, p. 248-255.

Godwin, H. and Willis, E., 1962, Cambridge University natural radiocarbon measurements V: Radiocarbon, v. 4, p. 57-70.

Haarnagel, W., 1965, Die Untersuchung einer spätbronze-früheisenzeitlichen Siedlung in Boomborg-Hatzum, Kreis Leer, in den Jahren 1963 und 1964 und ihr vorläufiges Ergebniss: Neue Ausgr. und Forsch. in Niedersachsen, v. 2, p. 132-164. 
Halbertsma, H., 1961, Bonifatius' levenseinde in het licht der opgravingen: Ber. Rijksdienst Oudheidk. Bodemond., v. 10-11, p. 395-444.

Hayen, H., 1957, Zur Bautechnik und Typologie der vorgeschichtlichen, frühgeschichtlichen und mittelalterlichen hölzernen Moorwege und Moorstrassen: Oldenburger Jahrb., v. 56, p. 87-189.

1963, Grosse Bohlenwege im Randmoor westlich der Unterweser: Praeh. Zeitschr., v. 41, p. 206-209.

Henri-Martin, G., 1964, La dernière occupation Moustérienne de la Quina (Charente). Datation par le radiocarbone: C. R. Acad. Sci. Paris, v. 258, p. 3533-3535.

Ivanova, I. K., 1962, Geologie der vielschichtigen paläolithischen Stationen von Molodowa am mittleren Dnestr (Russian text with German summary): Anthropozoikum, v. 11, p. 197-220.

Kohl, G. and Quitta, H., 1964, Berlin radiocarbon measurements I: Radiocarbon, v. 6 , p. $308-317$.

1966, Berlin radiocarbon measurements II: Radiocarbon, v. 8, p. 27-45.

Kretzoi, M. and Vértes, L., 1965, The role of vertebrate faunal and palaeolithic industries of Hungary in Quaternary stratigraphy and chronology: Acta Geol. Hungaria, v. 9, p. 125-143.

Leonardi, P., 1962, Nuova statione musteriana con resti di Leone speleo nella Grotta del Broion sui Colli Berici (Vicenza): Atti Accad. Naz. Lincei, Memorie, ser. 8, v. 6, p. $97-120$.

Leroi-Gourhan, A., 1961, Les fouilles d'Arcy-sur-Cure: Gallia-Préhistoire, v. 4, p. 3-16. Mason, R. J., 1965, The origin of South African society: S. African Jour. of Sci., v. 61, p. $255-267$.

Milojčić, V., 1959, Ergebnisse der Deutschen Ausgrabungen in Thessalien (1953-1958): Jahrb. Röm.-Germ. Zentralmus. Mainz, v. 6, p. 1-56.

Modderman, P. J. R., 1964, The Neolithic burial vault at Stein: Analecta Praehistorica Leidensia, v. 1, p. 3-16.

1966, Middle Bronze Age graves and settlement traces at Zwaagdijk, Gemeente Wervershoof, Prov. North Holland: Ber. Rijksdienst Oudheidk. Bodemond., v. 14, 1964, p. 27-36.

Morton, F., 1932, Das warme Wasser am Hallstätter See: Archiv für Hydrobiologie, v. 24, p. $543-546$

Movius, H. L., 1966, The hearths of the Upper Périgordian and Aurignacian horizons at the Abri Pataud, Les Eyzies (Dordogne), and possible significance: Am. Anthropol., v. 68, p. 296-325.

Münnich, K. O., 1957, Heidelberg natural radiocarbon measurements VII: Science, v. 126 , p. $194-199$.

Münnich, K.-O. und Vogel, J. C., 1959, Altersbestimmung von SüsswasserKalkablagerungen: Naturwiss., v. 46, p. 168.

Noten, F. van, 1965, "Strandlopers" aan de Kaap de Goede Hoop: Afrika-Tervuren, v. 11 , p. $58-60$.

Nowothnig, W., 1963, Neue Untersuchungen auf den Rentierjägerstationen von Deimern, Kr. Soltau: Nachr. aus Niedersachsens Urgeschichte, v. 32, p. 61-68.

Oeschger, H. and Riesen, T., 1965, Bern radiocarbon dates IV: Radiocarbon, v. 7, p. $1-9$.

Oeschger, H., Schwarz, U. and Gfeller, C., 1959, Bern radiocarbon dates I: Am. Jour. Sci. Radioc. Supp., v. 1, p. 133-143.

Olson, E. A., and Broecker, W. S., 1959, Lamont natural radiocarbon measurements V: Am. Jour. Sci. Radioc. Supp., v. 1, p 1-28.

Olsson, I., 1959, Uppsala natural radiocarbon measurements I: Am. Jour. Sci. Radioc. Supp., v. 1, p. 87-102.

Pradel, L., 1959, Le Périgordien II de la grotte des Cottés, commune de Saint-Pierre-deMaillé (Vienne): Bull. de la Soc. Préhist. Française, v. 56, p. 421-427.

1961, La grotte des Cottés, commune de Saint-Pierre-de-Maillé (Vienne): L'Anthrop., v. 65, p. 229-270.

van Regteren Altena, J. F. et al., 1962/63, The Vlaardingen Culture: Helinium, v. 2, p. $3-35$, p. $97-103$, p. $215-243$; v. 3 , p. $39-54$, p. $97-120$.

Remouchamps, A. E., 1926, Opgraving van een urnenveld te Goirle (N.B.): Oudh. Med. Rijksmus. Oudh. Leiden, v. 27, p. 92-109.

Rothenberg, B., 1962, Ancient copper industries in the Western Arabah: Palestine Explor. Quart., v. 94, p. 5-71. 
1965, Excavations at Timna (Arabah) May 1964 (Preliminary Report): Bull. Mus. Haaretz Tel Aviv, v. 7 , p. 19-28.

Smith, P. E. L., 1966, Le Solutréen en France: Publ. Inst. Préhist. de Univ. de Bordeaux. Mémoire no. 5, p. 449.

Soudsky, B., 1966, Bylany: Praha.

Stuckenrath, R. and Ralph, E. K., 1965, University of Pennsylvania radiocarbon dates VIII: Radiocarbon, v. 7, p. 187-199.

Tauber, H., 1960, Copenhagen natural radiocarbon measurements III: Am. Jour. Sci. Radioc. Supp., v. 2, p. 5-11.

Taute, W., 1967, Das Felsdach Lautereck, eine mesolithisch-neolithisch-bronzezeitliche Stratigraphie an der oberen Donau: Palaeohistoria (in press)

Verheyleweghen, J., 1963, Evolution chronologique du Néolithique au "Camp à Cayaux" de Spiennes (Hainaut): Helinium, v. 3, p. 3-38.

Vértes, L. 1959, Das Moustérien in Ungarn: Eiszeitalter u. Gegenwart, v. 11, p. 24-40. 1962, Ausgrabungen der altsteinzeitlichen Siedlung von Arka 1960-61: Acta Archaeol. Budapest, v. 14, p. 143-157.

Vértes, L. et al., 1964: Archaeol. Hungar., v. 43, p. 1-285.

Vogel, J. C., 1959, Uber den Isotopengehalt des Kohlenstoffs in SüsswasserKalkablagerungen: Geochim. et Cosmochim. Acta, v. 16, p. 236-242.

Vogel, J. C. and Waterbolk, H. T., 1963, Groningen radiocarbon dates IV: Radiocarbon, v. 5, p. 163-202.

1964, Groningen radiocarbon dates V: Radiocarbon, v. 6, p. 349-369.

Vogel, J. C. and Zagwijn, W., 1967, Groningen radiocarbon dates VI: Radiocarbon, v. 9 , p. $63-106$.

de Vries, Hl., 1953, Radiocarbon dating by a proportional counter filled with carbon dioxide: Physica, v. 19, p. 987-1003.

1957, The removel of radon from $\mathrm{CO}_{2}$ for use in ${ }^{14} \mathrm{C}$ age measurements: Appl. Sci. Res., v. 6, 461-470.

de Vries, Hl., and Barendsen, G. W., 1954, Measurements of age by the carbon-14 technique: Nature, v. 174, p. 1138-1146.

de Vries, Hl., Barendsen, G. W., and Waterbolk, H. T., 1958, Groningen radiocarbon dates II: Science, v. 127, p. 129-137.

de Vries, Hl., and Waterbolk, H. T., 1958, Groningen radiocarbon dates III: Science, v. 128 , p. $1550-1556$.

van der Waals, J. D., 1964a, Neolithic disc-wheels in the Netherlands. With a note on the Early Iron Age disc wheels from Ezinge: Palaeohistoria, v. 8, p. 103-146. 1964b, Prehistoric disc-wheels in the Netherlands: Groningen, thesis 1964. 1964c, Een klokbekergraf met crematieresten bij Hoog Buurlo (Gemeente Apeldoorn): Bijdr. en Meded. Ver. Gelre, v. 56, p. 69-76.

Waterbolk, H. T., 1964, The Bronze Age settlement of Elp: Helinium, v. 4, p. 97-131. Waterbolk, H. T. and van Zeist, W., 1967, Preliminary report on the Neolithic bog settlement of Niederwil: Palaeohistoria (in press).

Wreschner, E., Avnimelech, M., and Angres, S., 1960, The Geulah Caves, Haifa. Preliminary Report: Israel Explor. Jour., v. 10, p. 78-89.

van Zeist, W. 1955, Pollen analytical investigations in the northern Netherlands: Acta Botanica Neerlandica, v. 4. 